\title{
Contribution to the taxonomy of the Palaearctic species of the genus Laelius Ashmead, mainly from Finland and Sweden (Hymenoptera: Chrysidoidea: Bethylidae)
}

\author{
Veli Vikberg \& Martti Koponen
}

Vikberg, V. \& Koponen, M. 2005: Contribution to the taxonomy of the Palaearctic species of the genus Laelius Ashmead, mainly from Finland and Sweden (Hymenoptera: Chrysidoidea: Bethylidae). — Entomol. Fennica 16: 23-50.

A neotype is designated for Bethylus femoralis Förster, 1860 (now Laelius femoralis), and a lectotype for Bethylus rufipes Förster, 1860, nec Say 1824 (now Laelius foersteri Kieffer, 1914). Three new natural species are described from Southern Finland: Laelius borealis Vikberg sp. n. (also in S. Sweden), L. virilis Vikberg sp. n., and L. parcepilosus Vikberg sp. n.. The most common species in Sweden is described as Laelius fumimarginalis Vikberg sp. n. One imported indoor species, L. pedatus (Say), attacks larvae of Reesa vespulae (Milliron) (Coleoptera: Dermestidae) in Finland. The female of Laelius seticornis (Duchaussoy, 1916) is redescribed from La Palma, the Canary islands. All nominal species of Laelius from the Palaearctic region are listed and keys are presented for females and males of those examined.

V. Vikberg, Liinalammintie 11 as. 6, FI-14200 Turenki, Finland; E-mail: veli. vikberg@mail.htk.fi

M. Koponen, Department of Applied Biology, University of Helsinki, P. O. Box 27,FI-00014 University of Helsinki, Finland; E-mail: martti.a.koponen@helsinki.fi

Received 15 December 2003, accepted 12 August 2004

\section{Introduction}

The genus Laelius was established for four North American species by Ashmead \{1893; type species Laelius trogodermatis Ashmead, 1893 [= Laelius centratus (Say, 1836) by original designation]\}. Kieffer's (1914) monograph keyed and treated the species of the world. The species of Laelius were with unduly reasons divided among three genera: Allepyris Kieffer, 1905, Laelius Ashmead, and Paralaelius Kieffer, 1906. Ten species were known from the Palaearctic area, all from Central and South Europe, and seven of these were described by Kieffer (1906). Later
Kieffer's genera were synonymized with Laelius; Paralaelius by Muesebeck \& Walkley (1951), and Allepyris was treated as a synonym of Laelius by Perkins (1976). The North American species of the Bethylidae, among them of Laelius, were treated and revised by Evans $(1964,1978)$. Up to now, some 20 species (five of them in the genus Allepyris Kieffer) have been described mainly from the Holarctic region; two have been recorded from India, and one Nearctic species has been recovered in Mexico and Brazil [Gordh in Gordh \& Móczár (1990)]. Females of all species of which the biology is known, sting and paralyse dermestid larvae (Coleoptera: Dermestidae), pre- 
pare the larvae suitable for ovipositing by depilating the setae on their ventral abdomen, and lay one to six (rarely more) eggs there. The bethylid larvae feed externally on the host larva, and pupate in a cluster of cocoons near it (Vance \& Parker 1932, Yamada 1955, Evans 1964, Mertins 1980, 1985, Mayhew \& Heitmans 2000).

There is currently no modern treatment of, or key to, the European or Palaearctic species of Laelius. From the North European countries one species, viz. Laelius femoralis (Förster), has been reported from Finland by Hellén (1953), from Sweden by Hedqvist (1975), and from Norway by Hansen (1995). One imported N. American species, L. utilis Cockerell was further recorded from Sweden by Hedqvist (1975).

The purpose of this article is to add to our knowledge of the taxonomy of Palaearctic Laelius, and especially of the species that occur in Finland and Sweden.

\section{Material and methods}

The specimens of Laelius were studied from insect collections in Finland and Sweden, and some specimens were borrowed for comparison from other collections. Acronyms used for the institutes and collections are as follows: CKPC $=\mathrm{J}$.Christoph Kornmilch, private collection, Greifswald, Germany; DABH (former DAZH) = Department of Applied Biology, University of Helsinki, Finland (Martti Koponen); JAPC = Johan Abenius, private collection, Nynäshamn, Sweden; KUHMO = Ystävyyden puiston tutkimuskeskus, Kainuun ympäristökeskus, Kuhmo, Finland (Gergely Várkonyi); OULU = Zoological Museum, University of Oulu, Finland (Juhani Itämies); MTPC = Mamoru Terayama, private collection, Saitama, Japan; MVPC = Matti Viitasaari, private collection, Helsinki, Finland; NHMW = Naturhistorisches Museum Wien, Vienna, Austria, coll. G. Mayr (Stefan Schödl, Michael Madl); NHRS = Naturhistoriska Riksmuseet, Stockholm, Sweden, coll. K.-J. Hedqvist (Bert Viklund); RMNHL = Nationaal Natuurhistorisch Museum, Leiden, the Netherlands (Kees van Achterberg); VVPC = Veli Vikberg, private collection, Turenki, Finland; FMNH = Finnish Museum of Natural History, Department of Entomology, University of Helsinki, Finland (Anders Albrecht, Pekka Malinen).

Specimens of three strains of Laelius pedatus (Say) reared in a laboratory in the Netherlands were borrowed from RMNHL. They originated from Madison, Wisconsin, USA, and from two localities in the Netherlands (Mayhew \& Heitmans 2000).

The specimens were studied, descriptions, measurements and drawings were made by the first author (V. Vikberg) in a manner as described earlier (Vikberg \& Koponen 2001). Measurements are mainly the same as in Evans (1964, 1978). The length of the fore wing was measured from the apex of the humeral plate to the apex of the wing, and the width at the widest point across this longitudinal axis. The male genitalia were prepared as follows: the apical part of the gaster was cut, put into $\mathrm{KOH}$ for some hours, washed in plenty of water; terga, sterna, and genitalia were separated from each other, and after short treatment in lactic acid they were put into a drop of polyviol 17 on a slide, and a coverslip was put on. The morphological terms are mainly from Evans (1964, 1978) and/or Huber \& Sharkey (1993). The terms of male genitalia are according to Snodgrass (1941) and Richards (1977).

\section{Results}

\subsection{Designation of a neotype for Laelius femoralis (Förster, 1860) Figs. 1a-b, 2a-b, 3a}

Förster (1860) described only the male of Bethylus femoralis based on specimen(s) collected near Aachen. Kieffer (1906) transferred the species into the genus Laelius, and all later authors have followed him. After Förster obviously nobody has seen the syntype(s) (Gordh \& Móczár 1990). Attempts to trace the original material were made in the Zoologische Staatssammlung, Munich (Dr. Stefan Schmidt), the Humboldt University of Berlin (Dr. Frank Koch), the Deutsche Entomologische Institut, Eberswalde (Dr. Andreas Taeger), and the Natural History Museum, Vienna (Dr. Stefan Schödl and Mr. Michael Madl) without success. It is probably lost. To fix the nominal taxon, a neotype is needed. A female is optimal for the purpose, because its characters 


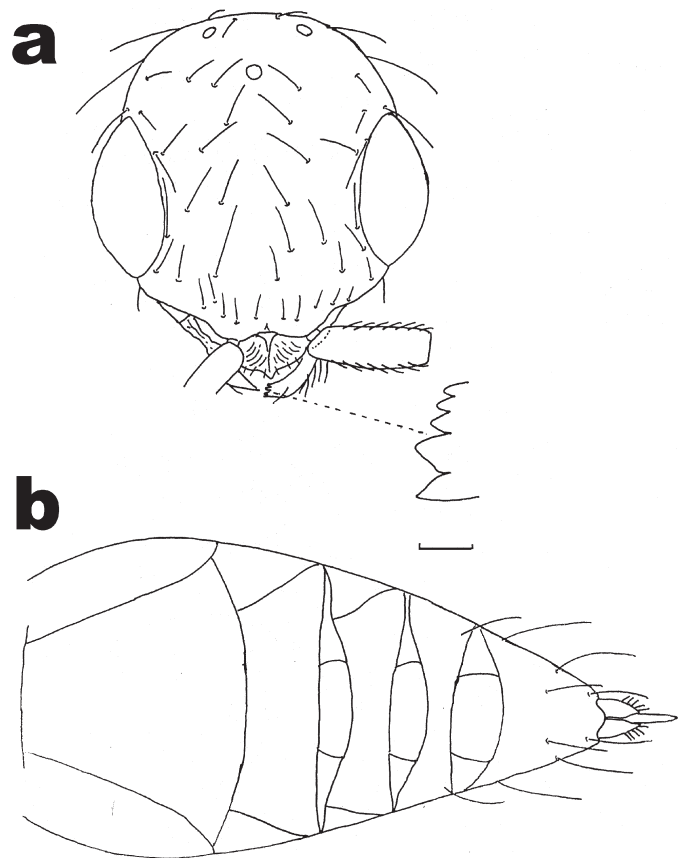

Fig. 1. Laelius femoralis (Förster), neotype female from Hilversum. - a. Head in anterior view, with apex of left mandible in larger scale. - b. Gaster in ventral view. Scale $0.1 \mathrm{~mm}$.

can be better evaluated than those of a male. The specimen should come from as near Aachen, Germany as possible. Laelius femoralis has been reported in several areas of Germany (de Rond 2002) but not near the original type locality. The selected female was collected ca. $170 \mathrm{~km} \mathrm{NW}$ of Aachen in the Netherlands, and its characters are described below.

Neotype female of Bethylus femoralis Förster, 1860 (hereby designated in order to fix the nominal taxon; coll. RMNHL) labelled: [Netherlands], Hilversum, Blijdesteijn, 19.VII. 1978, M. J. Gijswijt; Laelius femoralis (Foerster) q J. de Rond det. 1989; Opgenomen voor EISNederland; Neotype + Bethylus femoralis Förster, 1860, V. Vikberg 2003.

Description. Female neotype. Length of body 3.1 , of fore wing $1.85 \mathrm{~mm}$.

Head (Fig. 1a) 0.93 as wide as long; frons 1.19 as wide as the length of the eye; distance from eye to occipital carina 0.63 as long as eye length; sides of head roundly convergent behind eyes to a straight vertex; first 5 antennal segments in a ratio of about 25:14:8:8:9; first flagellomere 1.1 as long as wide; ocelli small, widely spaced; posterior width of ocellar triangle (WOT) 1.04 as long as ocello-ocular line (OOL); lateral side of ocellar triangle (LOT) shorter (0.86) than WOT; anterior angle of ocellar triangle slightly less than $90^{\circ}$; frons shining, with dark setae in ca. 4 longitudinal rows in addition to orbital setae, alutaceous, middle frons with engraved hexagonal or slightly irregular plates, in transverse direction ca. 8 plates/0.1 mm. Mandible 5-toothed (Fig. 1a), tooth 1 longest, tooth 2 widest, uppermost 3 teeth small and close to each other; apical margin of clypeus rounded, with a median tooth. Maxillary palpi 6-segmented, labial palpi 3-segmented.

Mesosoma 2.14 as long as wide (on pronotum near tegulae), 1.3 as wide as high. Pronotum near tegulae 1.5 as wide as its disc anteriorly. Thoracic dorsum similarly sculptured as head, engraved
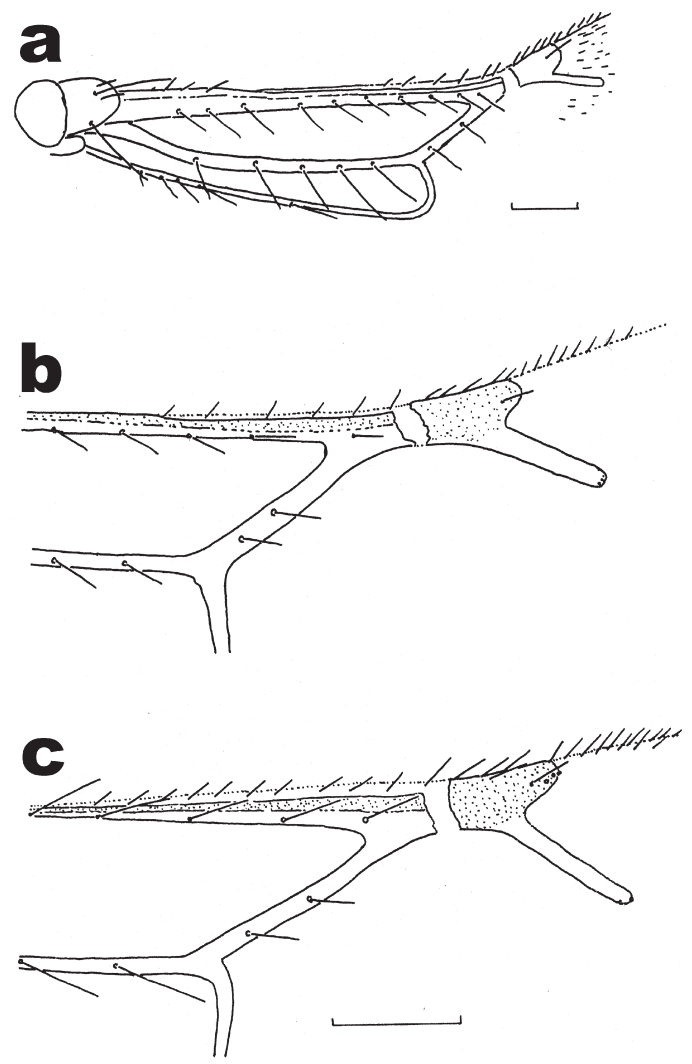

Fig. 2. Parts of fore wing of Laelius. - a-b. Laelius femoralis (Förster), neotype female from Hilversum. c. Laelius fumimarginalis Vikberg, sp. n., holotype female. Scale $0.1 \mathrm{~mm}$. 

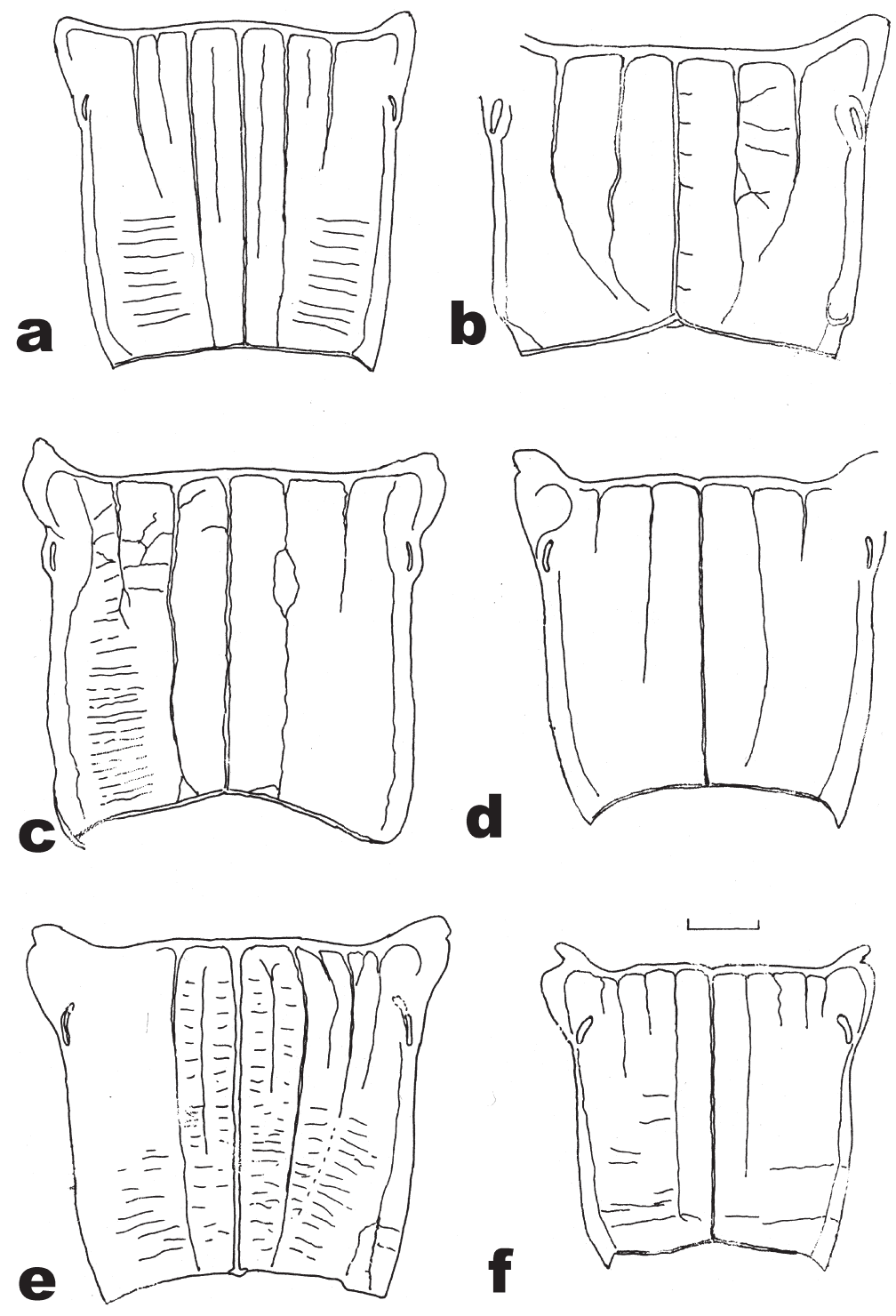

Fig. 3. Propodeal discs of females of Laelius. - a. L. femoralis (Förster), neotype. b. L. foersteri (Kieffer), lectotype. - c. L. borealis Vikberg, sp. n., holotype. - d. L. virilis Vikberg, sp. n., holotype. - e. L. fumimarginalis Vikberg sp. n., holotype. - f: L. sp. (?L. utilis Cockerell), from Arvika, Sweden. Scale $0.1 \mathrm{~mm}$.

sculpture on scutellum fine; notauli short, linear, diverge anteriad; propodeal disc (Fig. 3a) medially almost (0.98) as long as wide behind spiracles, with complete median and transverse carinae, and with two long submedian carinae which extend $0.7-0.9$ to transverse carina, and a short carina on either side of submedian carina (= altogether 7 discal carinae); long submedian carinae converge distad, their distance anteriorly 0.15 and posteriorly $0.09 \mathrm{~mm}$; surface between submedian carinae with irregular transverse striae defining mostly transverse, shining areolae, ca. 7 areolae $/ 0.1 \mathrm{~mm}$ in longitudinal direction; disc of propodeum laterally and posteriorly with regular transverse striae. Lateral carina strong, sublateral carina weak.

Wings. Fore wing 2.7 as long as wide; subcosta (Fig. 2a) with 10 strong dorsal setae; costa with 4 small setae; dorsal side of costal cell on apical margin over a distance of $0.20 \mathrm{~mm}$ with 6 small setae (Fig. 2b); stigma with 5 small setae near anterior margin and one short $(0.05 \mathrm{~mm})$ dorsal seta. Radius short and straight, 0.7 as long as basal vein. Hind wing with 3 hamuli.

Legs. Fore femur 2.6 as long as wide; hind femur 2.55 as long as wide. Outer hind claw with 
small denticle in apical 0.7 , and in basal half with one black seta arising from a low protuberance on lower margin, and one black seta on outer side of claw.

Metasoma. Gaster (Fig. 1b) caudally acute, 2.2 as long as wide, 1.15 as wide as high. Gaster broadest on posterior third of tergum 2 ; tergum 5 slightly incised medially. Three subapical sterna with broad, smooth caudal margin; margin is divided into three parts.

Colour. Black; mandible reddish brown, basal 0.3 infuscate; scape, pedicel reddish brown, upper side of scape diffusely infuscate; flagellum and palpi blackish brown; tegula and humeral plate brown; wings clear hyaline, veins pale yellowish, stigma and anterior margin of subcosta brown; mid-coxa brownish black, trochanters, tibiae and tarsi reddish brown, hind tibia diffusely infuscate; femora brownish black; caudal tergum and sternum reddish brown.

Measurements (lengths in mm unless stated otherwise). Body 3.1; head 0.70; head width 0.65 ; frons width 0.37 ; eye $0.31 \times 0.24$; distance of eye to occipital carina 0.20 ; malar space 0.11 ; WOT 0.20; POL 0.15; OOL 0.19; LOT 0.17; LOL 0.10; median ocellus: width 0.05 ; distance of lateral ocellus to occipital carina 0.08 ; scape 0.25; pedicel 0.14; flagellomere 1: 0.08, 2: 0.08, and 3: 0.09 ; mesosoma 1.22 (width 0.57 ); notaulus 0.06 ; median carina of propodeum 0.45 ; fore wing 1.85 ; costa 0.10 ; subcosta 0.62 ; basal vein 0.13 ; stigma 0.08 ; radius 0.09 ; hind wing 1.56; hind femur 0.45 ; hind tibia 0.58 (width 0.09 ), inner spur 0.12 , outer spur 0.06 ; hind tarsus 0.63 , basitarsus 0.24 ; metasoma (ventral view) 1.43; gaster 1.35 (width 0.63 ); median lengths of terga from base on $0.44,0.34,0.20,0.20,0.16$, 0.17 and 0.08 ; ovipositor sheath visible dorsally $0.09 \times 0.08$. Longest seta on temple 0.16 , on humeral plate 0.11 , on subcosta 0.09 , and on lateral metasoma 0.22 .

Notes. In coll. G. Mayr (NHMW) there is a female of Laelius femoralis originating from coll. A. Förster; it represents the same species as the neotype (Jeroen de Rond, pers. comm.). In the museum of Maastricht there is one conspecific female from Paarlo, the Netherlands, captured in Sept. 1966 by Sanders. Paarlo is situated $4 \mathrm{~km}$ SSE. of Roermond, so about $40 \mathrm{~km}$ north of Aachen (Jeroen de Rond, pers. comm.). The spe- cial structure of the apex of the gastral sterna 3-5 appears to be a characteristic of the females of the genus. In some females the median flap is projecting out of the gaster. Obviously the female can raise the median flaps out of the gaster when attacking or after attacking a dermestid larva and in order of getting rid of the adherent setae of the dermestid larva.

\subsection{Designation of a lectotype for Bethylus rufipes Förster, 1860, nec Say 1824 (= Laelius foersteri Kieffer, 1914). Figs. 3b, 4a, c}

Förster (1860: 108-109) described Bethylus rufipes based on one male and two females from the district near Aachen, Germany. Two females were present in coll. G. Mayr in NHMW, Vienna which are labelled: B. rufipes Förster, Type. One of them bears the label Frankfurt, and thus does not belong to the syntypes. The other female does not bear any locality label but instead it is labelled with a handwritten old label: Or. Ex., which means obviously Originales Exemplar. The female is a syntype. In order to fix the nominal taxon, it is hereby designated as the lectotype of Bethylus rufipes Förster, 1860. The specimen is labelled additionally "Collect. G. Mayr" and "B. rufipes [handwritten] Förster, Type [printed]". The micropinned female has later been glued on a piece of porous pith of some plant (probably Sambucus nigra L.) because the micropin was broken. The right antenna and metasoma are glued separately on the same pith. The wings have been broken away except the left fore wing; its setae are mostly worn away as are many setae on the head and the gaster. The lectotype is described herewith:

Description. Female lectotype of Bethylus rufipes. Length of body 3.2, of fore wing 1.80 $\mathrm{mm}$.

Head 0.99 as wide as long; frons 1.48 as wide as eye long; distance from eye to occipital carina 0.66 as long as eye length; sides of head roundly convergent behind eyes to a straight vertex; first 5 antennal segments in a ratio of about 24:13:9: 10:10; first flagellomere 1.5 as long as wide; ocelli small, widely spaced; posterior width of ocellar triangle (WOT) 1.16 as long as ocello-ocular line (OOL); lateral side of ocellar triangle 

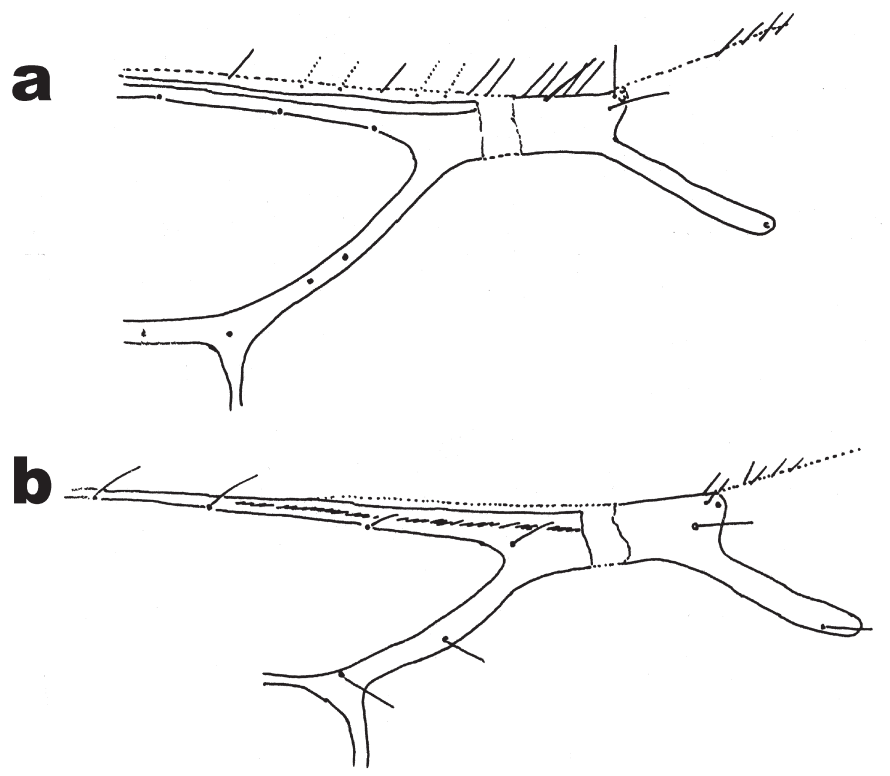

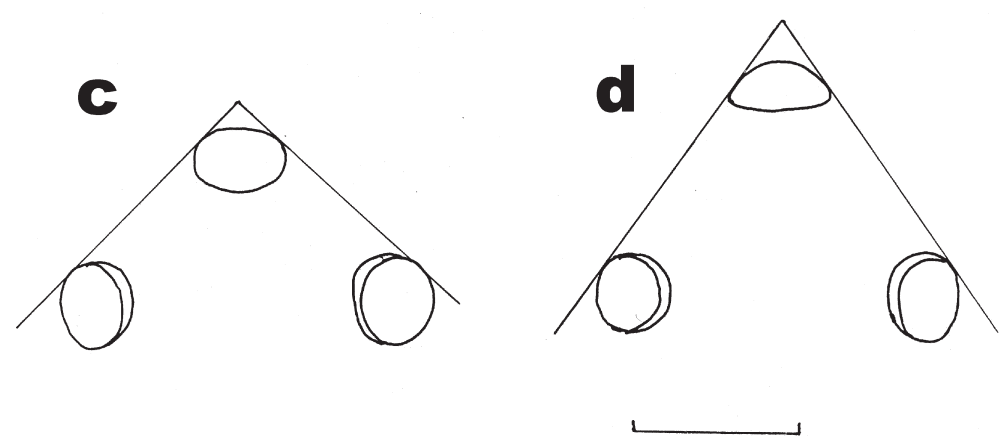

Fig. 4. Body parts of Laelius. - a. L. foersteri Kieffer, female from Frankfurt; part of fore wing. - b. L. parcepilosus Vikberg, sp. n., holotype female; part of fore wing. - c. L. foersteri Kieffer, lectotype female; ocellar triangle. - d. L. parcepilosus Vikberg, sp. n., holotype female; ocellar triangle. Scale $0.1 \mathrm{~mm}$.
(LOT) shorter (0.76) than WOT; anterior angle of ocellar triangle $90^{\circ}$ (Fig. 4c); frons shining, with dark setae in ca. 4 longitudinal rows in addition to orbital setae, alutaceous, middle frons with engraved hexagonal or slightly irregular plates, in transverse direction ca. 7 plates $/ 0.1 \mathrm{~mm}$. Mandible 5-toothed, upper 2 teeth small and close together; apical margin of clypeus rounded, with a median tooth. Maxillary palpi 6-segmented, labial palpi 3-segmented.

Mesosoma 1.88 as long as wide, 1.3 as wide as high. Pronotum near tegulae 1.63 as wide as its disc anteriorly. Thoracic dorsum similarly sculptured as head; notauli linear, diverge anteriad; propodeal disc (Fig. 3b) medially 0.74 as long as wide behind spiracles, with complete median and transverse carinae, also with two long submedian carinae which extend almost or reach to the transverse carina, and a short carina laterad of submedian carina extending $0.6-0.75$ to transverse carina (= altogether 5 discal carinae); surface between submedian carinae with wrinkled transverse striae, and shining, ovoid reticulation; disc of propodeum posterolaterally transversely striate; sublateral carina distinct; lateral carina strong, sharp.

Wings. Fore wing 2.43 as long as wide; radius short, narrow, straight, 0.77 as long as basal vein.

Legs. Fore femur 2.7 as long as wide; hind femur 2.85 as long as wide.

Metasoma. Gaster caudally pointed, 1.86 as long as wide, 1.21 as wide as high. Gaster broadest on posterior third of tergum 2; caudal margin of tergum 5 slightly incised medially.

Colour. Black; mandible yellowish brown, with base slightly infuscate; antenna brownish yellow, with flagellomeres 1-5 brownish; palpi brownish; tegula and humeral plate brownish yel- 
a
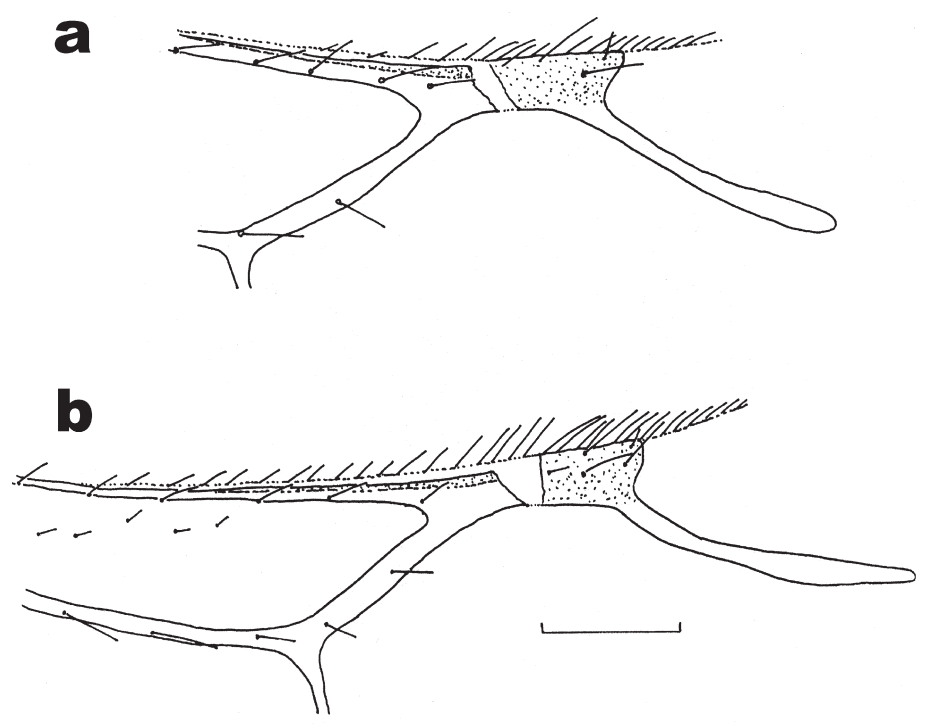

Fig. 5. Parts of fore wing of Laelius. - a. L. borealis Vikberg, sp. n., holotype female. - b. L. virilis Vikberg, sp. n., holotype female. - c. $L$. borealis Vikberg, sp. n., paratype male from Hämeenlinna. - Scale $0.1 \mathrm{~mm}$.

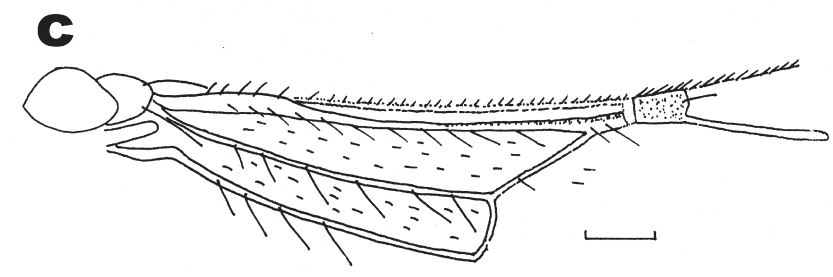

low; wings clear hyaline, veins pale yellowish; coxae brown, infuscate; legs otherwise brownishto reddish-yellow; gaster brownish black, with apex rufous; ovipositor sheath brown.

Measurements (in mm). Body 3.2; head 0.69; head width 0.68 ; frons width 0.43 ; eye $0.29 \times$ 0.23 ; distance of eye to occipital carina 0.19 ; malar space 0.13 ; WOT 0.23 ; POL 0.15 ; OOL 0.20; LOT 0.18; LOL 0.09; median ocellus: width 0.05 ; distance of lateral ocellus to occipital carina 0.10 ; scape 0.24 ; pedicel 0.13 ; flagellomere 1 : $0.09,2: 0.10$, and 3: 0.10; mesosoma 1.22 (width 0.65 ); notaulus 0.08 ; median carina of propodeum 0.40 ; fore wing 1.80 ; subcosta 0.61 ; basal vein 0.14 ; stigma 0.07 ; radius 0.11 ; hind femur 0.48 ; hind tibia 0.56 (width 0.08 ), inner spur 0.11 , outer spur 0.08 ; hind tarsus 0.59 , basitarsus 0.22 ; gaster 1.30 (width 0.70 ); median lengths of terga from base on $0.50,0.40,0.24,0.16,0.15$, 0.14 and 0.05 ; ovipositor sheath visible dorsally $0.11 \times 0.08$. Longest seta on temple 0.13 .

Notes. The female from Frankfurt in coll. G. Mayr is conspecific with the lectotype of $L$. rufipes. It is in a better condition than the lectotype. Head width 0.70 . Part of its fore wing is in Fig. 4a. Disc of propodeum: median length 0.42 ; width behind spiracles 0.53 . The name Bethylus rufipes Förster, 1860 is a junior primary homonym of Bethylus rufipes Say, 1824 which is a valid name for a N. American species of Epyris Westwood (Evans 1969, Krombein 1979). Kieffer (1914: 565) renamed Förster's species as Laelius foersteri. Ashmead (1893) also described a new species: Laelius rufipes, which was renamed by Kieffer (1908) as L. ashmeadi. L. foersteri was mixed with $L$. ashmeadi and placed as a synonym of L. tricarinatus Ashmead by Muesebeck (1939: 173). Gordh in Gordh \& Móczár (1990) placed L. foersteri wrongly under L. pedatus (Say), and used L. rufipes (Förster) as a valid name.

\subsection{Species of Laelius in Finland and Sweden}

Laelius borealis Vikberg sp. n., Figs. 3c, 5a, c, 6a Holotype female labelled: Suomi [=Finland], 
V [= Ab], Karjalohja [668:31], 14.7.1965, leg. J. Perkiömäki; Laelius femoralis Först. + , det. E. Valkeila; coll. Erkki Valkeila (DABH).

Description. Female holotype. Length of body 3.6 , of fore wing $2.05 \mathrm{~mm}$.

Head 0.96 as wide as long; frons 1.39 as wide as eye long; distance from eye to occipital carina 0.67 as long as eye length; sides of head roundly convergent behind eyes to a straight vertex; first 5 antennal segments in a ratio of about 30:16:9: 10:10; first flagellomere 1.1 as long as wide; ocelli small, widely spaced; posterior width of ocellar triangle (WOT) 0.95 as long as ocello-ocular line (OOL); lateral side of ocellar triangle (LOT) shorter (0.80) than WOT; anterior angle of ocellar triangle slightly less than $90^{\circ}$; frons shining, with dark setae in ca. 5 longitudinal rows in addition to orbital setae, alutaceous; middle frons with engraved hexagonal or slightly irregular plates, in transverse direction ca. 7 plates $/ 0.1 \mathrm{~mm}$. Mandible 5-toothed, upper 2 teeth small and close together; apical margin of clypeus rounded, with a median tooth. Maxillary palpi 6-segmented, labial palpi 3-segmented.

Mesosoma 2.16 as long as wide, 1.3 as wide as high. Pronotum 1.5 as wide as its disc anteriorly. Thoracic dorsum similarly sculptured as head; notauli short, ovoid; propodeal disc (Fig. 3c) medially 0.92 as long as wide behind spiracles, with complete median and transverse carinae, with two long submedian carinae which extend to the transverse carina, and laterally with a short carina (= altogether 5 discal carinae); long submedian carinae converge strongly near transverse carina, their distance maximally 0.19 and on transverse carina $0.07 \mathrm{~mm}$; surface between submedian carinae mostly with elevated reticulate sculpture, small areolae roundish or ovoid, shining; disc of propodeum laterally transversely striate.

Wings. Fore wing 2.7 as long as wide; subcosta with 11-12 strong dorsal setae; costa with five small setae; costal cell (Fig. 5a) apically with 6 small setae; stigma with 5 small setae near anterior margin and one short $(0.06 \mathrm{~mm})$ dorsal seta. Radius almost straight, apically very slightly broadened, 1.03-1.11 as long as basal vein. Basal cell with 1 or 2 small setae. Hind wing with 3 hamuli.

Legs. Fore femur 2.7 as long as wide; hind fe- mur 2.65 as long as wide.

Metasoma. Gaster caudally acute, 1.96 as long as wide, 1.25 as wide as high. Gaster broadest on posterior third of tergum 2 ; tergum 5 slightly incised medially.

Colour. Black; mandible reddish brown, with base slightly infuscate; scape, pedicel reddish brown, 0.7 of upper side of scape diffusely infuscate; flagellum and palpi dark brown; tegula and humeral plate brown; wings clear hyaline, veins pale yellowish, stigma and anterior margin of subcosta pale brown; coxae and femora brownish black; trochanters, tibiae and tarsi reddish brown, mid- and hind tibia diffusely infuscate; caudal tergum and sternum reddish brown.

Measurements (in mm). Body 3.6; head 0.76; head width 0.73 ; frons width 0.46 ; eye $0.33 \times$ 0.25 ; distance of eye to occipital carina 0.22 ; malar space 0.12 ; WOT 0.23 ; POL 0.15 ; OOL 0.24 ; LOT 0.18; LOL 0.12; median ocellus: width 0.06 ; distance of lateral ocellus to occipital carina 0.11 ; scape 0.30 ; pedicel 0.16 ; flagellomere 1 : $0.09,2$ : 0.10 , and 3: 0.10; mesosoma 1.45 (width 0.67 ); notaulus 0.03 ; median carina of propodeum 0.47 ; fore wing 2.05 ; subcosta 0.72 ; basal vein 0.17 ; stigma 0.09 ; radius $0.17-0.20$; hind femur 0.53 ; hind tibia 0.66 , inner spur 0.11 , outer spur 0.07 ; hind tarsus 0.68 ; metasoma (ventrally) 1.55; gaster 1.45 (width 0.74 ); median lengths of terga from base on $0.53,0.42,0.30,0.13,0.11$, 0.15 and 0.04 ; ovipositor sheath visible dorsally $0.10 \times 0.07$. Longest seta behind eye 0.16 , on humeral plate 0.15 , and lateral metasoma 0.21 .

Variation of Finnish females, mean (and range in parenthesis; number of measurements $=13$ ): Body 2.8-3.85 mm. Fore wing 1.83 (range 1.652.15). Head width $0.67(0.61-0.75)$, head 0.95 (0.93-0.97) as wide as long. Pterostigma: dorsal seta $0.06(0.04-0.07)$; radius $0.16(0.14-0.20$ $\mathrm{mm})$ or $1.07(1.00-1.17 ; n=18)$ as long as basal vein. Subcosta with $10(8-12)$ dorsal setae. Costa with 4 (3-6) small dorsal setae. Costal cell apically on upper surface with 4.5 (3-6) small setae. Basal cell with 0.4 small setae $(0-2 ; n=22)$. Notaulus short, $0.03(0.0-0.07 ; n=19)$

Male. Paratype from Hämeenlinna (Ta). Length of body 2.6, of fore wing $2.0 \mathrm{~mm}$.

Head 1.05 as wide as long; frons 1.44 as wide as eye long; distance from eye to occipital carina 
0.68 as long as eye length; sides of head roundly convergent behind eyes to a straight vertex; first 5 antennal segments in a ratio of about 21:11:10: 10:11, first flagellomere 1.7 as long as wide; ocelli widely spaced; posterior width of ocellar triangle (WOT) 1.43 as long as ocello-ocular line (OOL); lateral side of ocellar triangle (LOT) shorter (0.84) than WOT; anterior angle of ocellar triangle slightly less than $90^{\circ}$; frons shining, with dark setae in 4-5 longitudinal rows in addition to orbital setae, alutaceous, middle frons with engraved hexagonal or slightly irregular plates, in transverse direction 8-9 plates/0.1 mm. Mandible 5-toothed, upper 2 teeth small and close together; apical margin of clypeus rounded, with a sharp median tooth. Maxillar palpi 6-segmented, labial palpi 3-segmented.

Mesosoma 2.1 as long as wide, 1.18 as wide as high. Pronotum 1.8 as wide as its disc anteriorly. Thoracic dorsum similarly sculptured as head; notauli short, foveate, ovoid, anteriorly indicated by dense, small, alutaceous microsculpture; propodeal disc 1.08 as long as wide behind spiracle, with complete median carina, posterior half of it weak, wrinkled; laterad of median carina two short, weak and wrinkled carinae on both sides; lateral and transverse carinae present but weak; propodeal disc medially with elevated reticulate, ovoid sculpture, laterally transversely striate.

Wings. Fore wing 2.3 as long as wide; subcosta (Fig. 5c) with 11-12 dorsal setae; costa with 5-6 small setae on anterior margin; upper side of costal cell setose throughout; stigma with 6 small setae near anterior margin and one short (0.05 mm) dorsal seta. Radius $1.14-1.17$ as long as basal vein, almost straight, equally thin. Basal and subbasal cells setose, setae small. Hind wing with 3 hamuli.

Legs. Fore femur 3.4 as long as wide; hind femur 3.3 as long as wide.

Metasoma. Gaster caudally pointed, 2.0 as long as wide, 1.28 as wide as high. Gaster broadest on posterior third of tergum 2. Penis: Fig. 6a.

Colour. Black; mandible reddish to yellowish brown, with base infuscate; scape infuscate; pedicel and flagellum reddish brown; palpi brown; tegula and humeral plate yellowish brown; wings clear hyaline, veins pale yellowish, stigma and anterior margin of subcosta pale brown; coxae and femora brownish black; trochanters, tibiae and tarsi yellowish brown, mid- and hind tibia diffusely infuscate; gaster brownish black, apically reddish brown.

Measurements (in mm). Body 2.6; head 0.55; head width 0.58 ; frons width 0.36 ; eye $0.25 \times$ 0.21 ; distance of eye to occipital carina 0.17 ; malar space 0.07 ; WOT 0.22 ; POL 0.13 ; OOL 0.15 ; LOT 0.18; LOL 0.08; median ocellus: width 0.07 ; distance of lateral ocellus to occipital carina 0.08 ; scape 0.21 ; pedicel 0.11 ; flagellomere 1 : $0.10,2$ : 0.10 , and 3: 0.11 ; mesosoma 1.12 (width 0.53 ); notaulus $0.01-0.03$; median carina of propodeum 0.41 ; fore wing 2.0 ; subcosta 0.70 ; basal vein 0.18 ; stigma 0.09 ; radius 0.21 ; hind femur 0.41 ; hind tibia 0.50 , inner spur 0.10 , outer spur 0.07; hind tarsus 0.56 ; metasoma (ventrally) 1.00; gaster 0.92 (width 0.46 ); median lengths of terga from base on $0.31,0.30,0.13,0.11,0.08$, 0.04 and 0.03 . Longest seta behind eye 0.12 , on humeral plate 0.11 , and lateral metasoma 0.15 .

Paratypes. Finland, Al: Mariehamn ("Maarianhamina", Ytternäs, Grid 27²E 668:10), 11.VII.1966 1 †, J. Perkiömäki leg. (DABH). Ab: Rymättylä [670:22], 21.VII.1967 1 q, E. Valkeila leg. (DABH). N: Hanko (Tvärminne, 664:28), 19271 q, W. Hellén leg. (FMNH); Nurmijärvi (Rajamäki, 6715:376), 18.VII.1981 1 q, M. Koponen leg. (DABH). Ka: Hamina ("Vehkalahti", 671:51), 22.VIII.1962 1 †, V. Vikberg leg. (VVPC). Virolahti (6709:525), 24.VII.1981 1 ㅇ, H. Luoma leg. (MVPC). Ta: Hämeenlinna (676:36), 17.VII.1975 1 đ, E. Valkeila leg. (DABH); Tampere [682:32], 2.VII.1962 1 , T. Grönblom leg. (DABH). Sa: Ristiina (6826:502), 9.VII.1978 1 (indoors), 27.VI.1992 1 ㅇ, M. Koponen leg. (DABH). Sb: Savonranta (6908:602), 10.VIII-4.IX.1996 1 q; (Muhamäki 6910:604), 13.VII-10.8.1996 1 q, 10.VIII-4.IX.1996 1 q, all three from window trap on dead aspen, P. Martikainen leg. (DABH).

Other specimens (not paratypes): Sweden, Sm.: Långemåla, Hornsö, 18.7.1942 1 †, O. Lundblad leg. (NHRS). Sdm.: Vingåker, 13.7.1978 1 q, K.-J. Hedqvist leg. (NHRS).

Biology. Three females in Savonranta (Sb) were captured in window traps on trunks of dead aspen (Martikainen 2001). Several dermestid species were captured in the same window traps in Savonranta (Dr. Petri Martikainen, pers. 
comm.): Anthrenus museorum (Linnaeus), Dermestes lardarius Linnaeus, D. murinus Linnaeus, Globicornis emarginata (Gyllenhal), Megatoma undata (Linnaeus), and Trogoderma glabrum (Herbst). Host unknown. Possible hosts could be Globicornis emarginata, Megatoma undata or Ctesias serra (Fabricius) whose larvae are free living under the bark of trees.

Notes. The characters of two Swedish females are as follows (female from $\mathrm{Sdm}$. is smaller of two): Body 3.4-3.6 mm. Fore wing clear, 1.852.0. Head width 0.67-0.75. Head 0.93 (Sdm.) or $1.01(\mathrm{Sm}$.$) as wide as long. Pterostigma: dorsal$ seta $0.05-0.07$; radius $0.13-0.17 \mathrm{~mm}$ or $0.93-$ 1.06 as long as basal vein. Subcosta with 8-9 dorsal setae. Costa with 3-4 setae on upper surface. Apical $0.15 \mathrm{~mm}$ of costal cell on upper surface with 7-10 setae; these are closer to each other than in females of L. fumimarginalis. Notaulus 0.06-0.10. The sculpture of anterior propodeum of female from $\mathrm{Sm}$. is rough. The only female of Laelius femoralis reported from Finland by Hellén (1953) is actually a large specimen of $L$. borealis. Thus Laelius femoralis should be removed from the recent checklist of Finnish Aculeata (Söderman and Vikberg 2003), and Bethylus rufipes Förster, nec Say, now L. foersteri Kieffer, listed as its synonym, is a distinct species which does not occur in Finland.

Laelius virilis Vikberg sp. n., Figs. 3d, 5b, 6b

Holotype female labelled Fennia [= Finland], Ta: Hämeenlinna (677:36), 14.VIII.1977, E. Valkeila leg.; coll. Erkki Valkeila (DABH).

Description. Female holotype. Length of body 3.2 , of fore wing $2.0 \mathrm{~mm}$.

Head 0.96 as wide as long; frons 1.43 as wide as eye long; distance from eye to occipital carina 0.67 as long as eye length; sides of head roundly convergent behind eyes to a straight vertex; first 5 antennal segments in a ratio of about 26:13:8: 10:9, first flagellomere 1.14 as long as wide; ocelli small, widely spaced; posterior width of ocellar triangle (WOT) 0.83 as long as ocello-ocular line (OOL); lateral side of ocellar triangle (LOT) shorter (0.95) than WOT; anterior angle of ocellar triangle slightly less than $90^{\circ}$; frons shining, with dark setae in ca. 7 longitudinal rows in addition to orbital setae, alutaceous, middle frons with engraved hexagonal or slightly irregular plates, in transverse direction ca. 6 plates $/ 0.1 \mathrm{~mm}$. Mandible 5-toothed, upper 2 teeth small and close together; apical margin of clypeus rounded, with a median tooth. Maxillary palpi 6-segmented, labial palpi 3-segmented.

Mesosoma 2.1 as long as wide near tegulae, 1.3 as wide as high. Pronotum near tegulae 1.5 as wide its disc anteriorly. Thoracic dorsum similarly sculptured as head; notauli long, linear, diverge anteriad; propodeal disc (Fig. 3d) medially 0.93 as long as wide behind spiracles, with complete median and transverse carinae, also with two rather long submedian carinae which extend $0.7-0.9$ to transverse carina, and a short carina laterad of submedian carina (= altogether 5 discal carinae); surface between submedian carinae mostly with elevated reticulate sculpture, small areolae roundish or ovoid, shining; disc of propodeum laterally transversely striate.

Wings. Fore wing 2.6 as long as wide; subcosta with 9-10 strong dorsal setae; costa with 56 small setae on upper margin; basal cell with 6-9 and subbasal cell apically with 3 setae; costal cell (Fig. 5b) apically with 15-16 small setae; stigma with 5 small setae near anterior margin and one short $(0.05 \mathrm{~mm})$ dorsal seta. Radius long, slightly curved, in apical half very slightly broadened, $1.56-1.77$ as long as basal vein. Hind wing with 3 hamuli.

Legs. Fore femur 2.8 as long as wide; hind femur 2.55 as long as wide.

Metasoma. Gaster caudally pointed, 1.94 as long as wide, 1.18 as wide as high. Gaster broadest on posterior third of tergum 2; tergum 5 slightly incised medially.

Colour. Black; mandible yellowish brown, with base infuscate; scape, pedicel yellowish brown, 0.7 of upper side of scape infuscate; flagellum and palpi dark brown; tegula and humeral plate brown; wings clear hyaline, veins pale yellowish, stigma and anterior margin of subcosta pale brown; coxae and femora brownish black; trochanters, tibiae and tarsi yellowish brown; gaster brownish black, with apex reddish brown.

Measurements (in mm). Body 3.2; head 0.69; head width 0.66 ; frons width 0.43 ; eye $0.30 \times$ 0.23 ; distance of eye to occipital carina 0.20 ; malar space 0.10 ; WOT 0.19 ; POL 0.12 ; OOL 0.23; LOT 0.18; LOL 0.09; median ocellus: width 
Fig. 6. Penis of Laelius in dorsal view (a) or ventral view $(b-c)$. $-a$. L. borealis Vikberg, sp. n., paratype. - b. $L$. virilis Vikberg, sp. $\mathrm{n}$., paratype. - c. L. fumimarginalis Vikberg, sp. n., paratype from Vallentuna, Sweden. Scale $0.1 \mathrm{~mm}$.
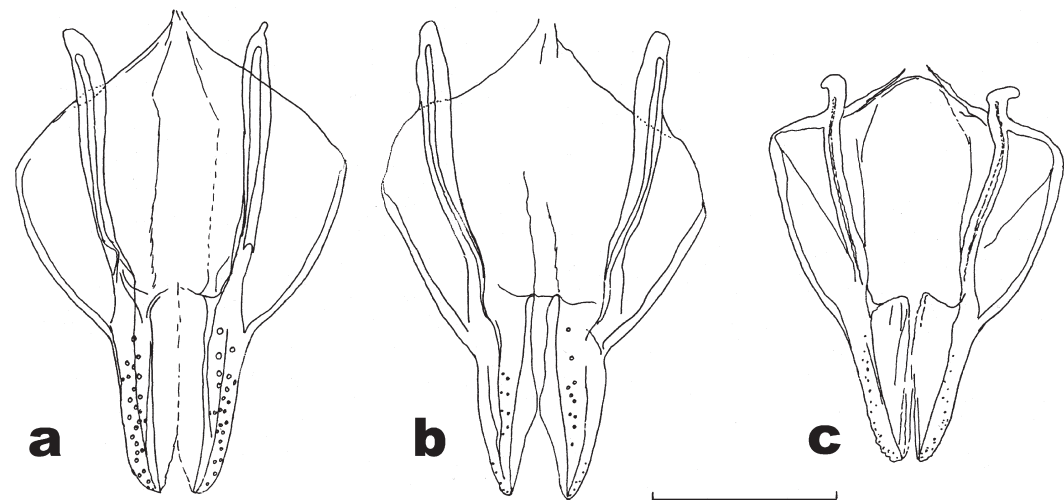

slightly (0.94) shorter than WOT; anterior angle of ocellar triangle slightly less than $90^{\circ}$; frons shining, with dark setae in 8-9 longitudinal rows in addition to orbital setae, alutaceous, middle frons with engraved hexagonal or slightly irregular plates, in transverse direction ca. 8 plates $/ 0.1$ $\mathrm{mm}$. Mandible 5-toothed, upper 2 teeth small and close together; apical margin of clypeus rounded, with a sharp median tooth. Maxillary palpi 6-segmented, labial palpi 3-segmented.

Mesosoma 2.1 as long as wide, 1.2 as wide as high. Pronotum 1.66 as wide as its disc anteriorly. Thoracic dorsum similarly sculptured as head; notauli long, linear, posteriorly stronger, diverging anteriad; propodeal disc 1.11 as long as wide behind spiracle, anteriorly with weak and short median carina; laterad of median carina one to two short, weak and wrinkled carinae on both sides; lateral and transverse carinae present but weak; propodeal disc medially with elevated reticulate, ovoid sculpture, laterally transversely striate.

Wings. Fore wing 2.4 as long as wide; subcosta with 13-14 dorsal setae; costa with 5-6 small setae on anterior margin; dorsal, anterior margin of costal cell setose throughout, with 28 setae; stigma with 6 small setae near anterior margin and one short $(0.05 \mathrm{~mm})$ dorsal seta. Radius long, $1.54-1.81$ as long as basal vein, slightly curved, almost equally narrow. Basal and subbasal cells setose, setae small. Hind wing with 3 hamuli.

Legs. Fore femur 3.3 as long as wide; hind femur 2.85 as long as wide.

Metasoma. Gaster caudally pointed, 1.95 as long as wide, 1.3 as wide as high. Gaster broadest (OOL); lateral side of ocellar triangle (LOT) 
on posterior third of tergum 2. Penis: Fig. $6 b$.

Colour. Black; mandible reddish brown, with base infuscate; scape infuscate; pedicel brown; flagellum and palpi dark brown; brown; tegula and humeral plate brown; wings clear hyaline, veins pale yellowish, stigma and anterior margin of subcosta pale brown; coxae brownish black; femora brownish, infuscate; trochanters, tibiae and tarsi brownish; gaster brownish black, apically reddish brown.

Measurements (in mm). Body 2.4; head 0.52; head width 0.56 ; frons width 0.34 ; eye $0.25 \times$ 0.20 ; distance of eye to occipital carina 0.14 ; malar space 0.07; WOT 0.17; POL 0.09; OOL 0.15 ; LOT 0.16; LOL 0.07; median ocellus: width 0.06 ; distance of lateral ocellus to occipital carina 0.09 ; scape 0.19 ; pedicel 0.09 ; flagellomere 1 : $0.09,2: 0.10$, and 3: 0.10; mesosoma 1.01 (width 0.48 ); notaulus $0.07-0.17$; median length of propodeal disc 0.40 ; fore wing 1.97 ; subcosta 0.64 ; basal vein 0.18 ; stigma 0.08 ; radius $0.27-$ 0.32 ; hind femur 0.37 ; hind tibia 0.49 , inner spur 0.08 , outer spur 0.05 ; hind tarsus 0.54 ; metasoma (ventrally) 0.96 ; gaster 0.84 , median lengths of terga from base on $0.26,0.25,0.15,0.11,0.09$, 0.03 and 0.04 . Longest seta on temple 0.10 , on humeral plate 0.10 , and on lateral gaster 0.18 .

Paratypes. Finland, Ta: Hämeenlinna ("Vanaja" 676:36), 10.VII.1954 1 q, E. Valkeila leg. (OULU); Hattula [677:35], 25.VII.1954 1 , (676:35) 9.VII.1972 1 q, E. Valkeila leg. (DABH); Renko (675:34), 19.VII.1975 2 , V. Vikberg leg. (VVPC). Sa: Ristiina (6826:502), 11.VIII.1987 1 §, M. Koponen leg. (DABH).

Biology. The females in Renko (Ta) were collected on the wall of an old log cottage. Host is unknown. Possible candidate on walls of old log cottage is Megatoma undata (Linnaeus) (Coleoptera, Dermestidae, Megatominae).

Etymology. The female of the species shows some "masculine" characters: long notauli, basal and costal cells with several setae, and a long radial vein. Therefore the specific name virilis.

Laelius fumimarginalis Vikberg sp. n., Figs. 2c, $3 \mathrm{e}, 6 \mathrm{c}, 7 \mathrm{a}-\mathrm{c}$

Holotype female labelled [Sweden,] Sk.: Vittskövle, 20.7.1974, K.-J. Hedqvist leg. (NHRS)

Description. Female holotype. Length of body 3.3 , of fore wing $1.95 \mathrm{~mm}$.
Head 0.92 as wide as long; frons 1.18 as wide as eye long; distance from eye to occipital carina 0.65 as long as eye length; sides of head roundly convergent behind eyes to a straight vertex; first 5 antennal segments in a ratio of about 27:13:9:10:10, first flagellomere 1.3 as long as wide; ocelli small, widely spaced; posterior width of ocellar triangle (WOT) 1.16 as long as ocelloocular line (OOL); lateral side of ocellar triangle (LOT) shorter (0.77) than WOT; anterior angle of ocellar triangle ca. $90^{\circ}$; frons shining, with dark setae in ca. 4 longitudinal rows in addition to orbital setae, alutaceous, middle frons with engraved hexagonal or slightly irregular plates, in transverse direction ca. 7 plates $/ 0.1 \mathrm{~mm}$. Mandible 5-toothed, upper 2 teeth small and close together; apical margin of clypeus rounded, with a median tooth. Maxillary palpi 6-segmented, labial palpi 3-segmented.

Mesosoma 2.13 as long as wide (on pronotum near tegulae), 1.3 as wide as high. Pronotum near tegulae 1.44 as wide its disc anteriorly. Thoracic dorsum similarly sculptured as head, engraved sculpture on scutellum fine; notauli short, linear, diverge anteriad; propodeal disc (Fig. 3e) medially 0.96 as long as wide behind spiracles, with complete median carina and two submedian carinae which extend to transverse carina although weak posteriorly, and a short carina on either side of submedian carina (= altogether 7 discal carinae); submedian carinae converge distad, their distance anteriorly 0.15 , maximally 0.20 and posteriorly $0.10 \mathrm{~mm}$; surface between submedian carinae with irregular transverse striae defining mostly transverse shining areolae, partly reticulate; disc of propodeum laterally and posteriorly with oblique striae directed out- and backwards. Lateral carina strong, sublateral carina weaker.

Wings. Fore wing 2.64 as long as wide; subcosta with 9-11 strong dorsal setae; costa short $(0.10 \mathrm{~mm})$, with 3 small setae; upper surface of costal cell (Fig. 2c) with 11 small setae on apical $0.27 \mathrm{~mm}$; basal cell glabrous; stigma with 5 small setae near anterior margin and one short $(0.05 \mathrm{~mm})$ dorsal seta. Radius short and straight, 0.7 as long as basal vein. Hind wing with 3 hamuli.

Legs. Fore femur 2.5 as long as wide; hind femur 2.6 as long as wide. 
Fig. 7. Laelius fumimarginalis Vikberg, sp. n., paratype male from Vallentuna, Sweden. - a. Sternum 8. - b. Tergum 9, with pygostyles. - c. Sternum 9 . Scale $0.1 \mathrm{~mm}$.

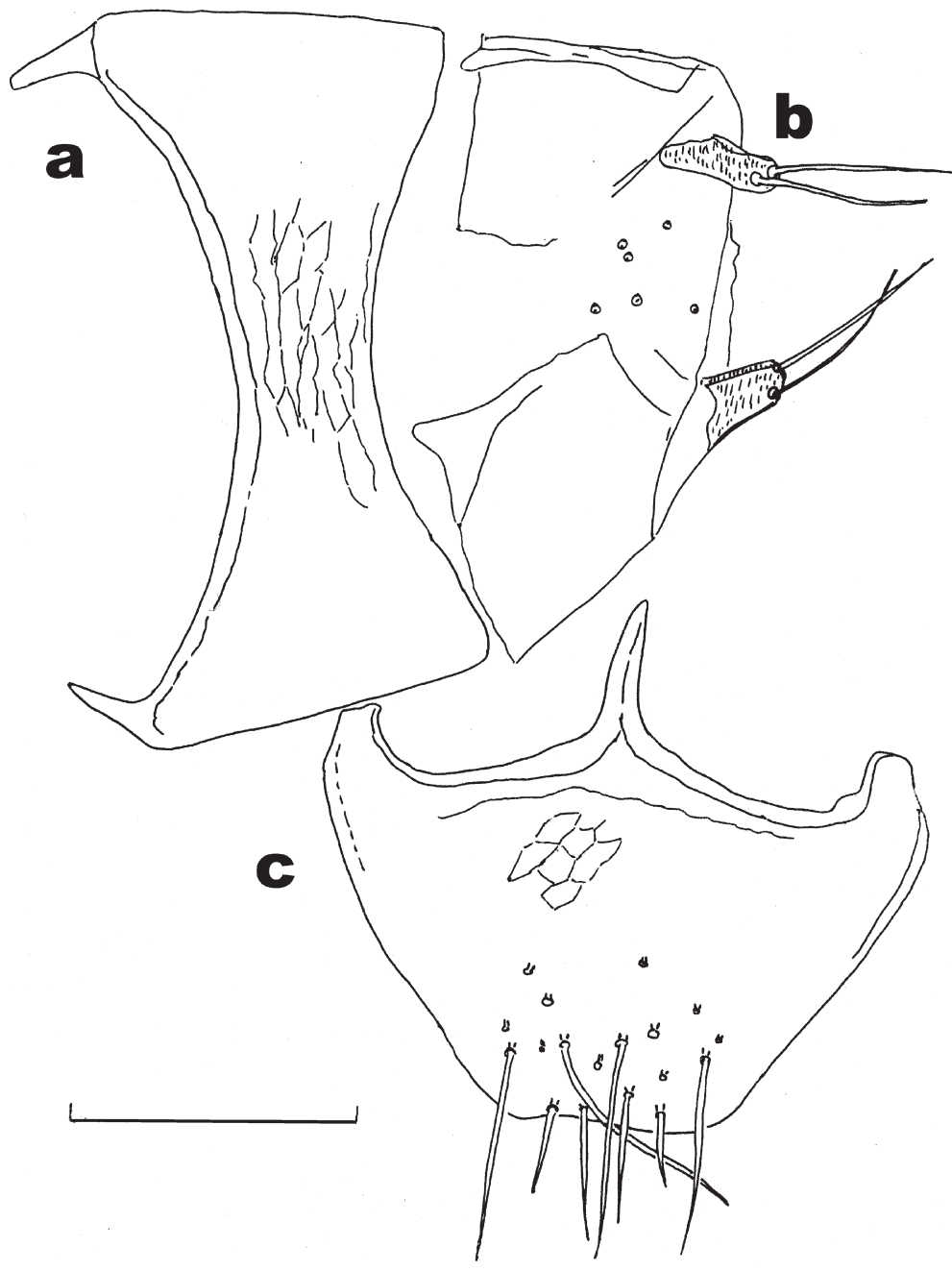

Metasoma. Gaster caudally acute, broadest on posterior third of tergum 2; tergum 5 slightly incised medially.

Colour. Black; mandible reddish brown, basally slightly infuscate; scape, pedicel reddish brown, base of scape slightly infuscate; flagellum blackish brown; palpi brownish; tegula and humeral plate brown; wings clear hyaline, veins pale yellowish, stigma and anterior margin of subcosta brown; right fore wing with a faint brownish cloud on anterior apical part beginning near stigma; mid-coxa brownish black, trochanters, tibiae and tarsi reddish brown, hind tibia diffusely infuscate; femora brownish black; caudal tergum and sternum reddish brown.

Measurements (lengths in mm). Body 3.3; head 0.74 ; head width 0.68 ; frons width 0.39 ; eye
$0.33 \times 0.25$; distance of eye to occipital carina 0.22 ; malar space 0.12 ; WOT 0.24; POL 0.17 ; OOL 0.20; LOT 0.18; LOL 0.12; median ocellus: width 0.05 ; distance of lateral ocellus to occipital carina 0.08 ; scape 0.27 ; pedicel 0.13 ; flagellomere $1: 0.09,2: 0.10$, and $3: 0.10$; mesosoma 1.32 (width 0.62 ); notaulus $0.02-0.03$; median carina of propodeum 0.47 ; fore wing 1.95; subcosta 0.68 ; basal vein 0.15 ; stigma 0.09 ; radius 0.11 ; hind femur 0.50 ; hind tibia 0.58 (width 0.095 ), inner spur 0.11 , outer spur 0.07 ; hind tarsus 0.67 , basitarsus 0.25 ; gaster 1.30. Longest seta on temple 0.13 , on humeral plate 0.11 , and on lateral gaster 0.20 .

Variation of Swedish females $(n=10)$ : Body 3.2 (2.5-3.6). Fore wing 1.85 (1.48-2.08). Head width $0.64(0.53-0.70)$, head $0.92(0.91-0.94)$ as 
wide as long. Number of hair rows on upper frons 3.5 (2-5). Dorsal seta of pterostigma $0.05(0.04$ $0.06)$. Radius $0.10(0.07-0.12)$ or $0.70(0.57-$ 0.79 ) as long as basal vein. Subcosta with 9.1 (711) dorsal setae. Costa with 4 (2-7) setae on dorsal margin. Upper surface of costal cell with 9.4 (7-12) setae on apical $0.22-0.32 \mathrm{~mm}$. Basal cell glabrous, only one female with one seta on one wing. Notaulus short, length $0.03(0.0-0.10 ; n=$ 17). Median length of propodeal disc 0.97 (0.941.04) as long as wide behind spiracles. Brownish infumation present on both fore wings of $6 \mathrm{fe}$ males, on one wing of two females, and absent in two females.

Male. paratype from Vallentuna (Upl., indoors 5.II.1970).

Length of body $2.5 \mathrm{~mm}$ and that of fore wing $1.95 \mathrm{~mm}$.

Head 1.04 as wide as long; frons 1.34 as wide as eye long; distance from eye to occipital carina 0.66 as long as eye length; sides of head roundly convergent behind eyes to a straight vertex; first 5 antennal segments in a ratio of about 19:9:9: 10:10, first flagellomere 1.5 as long as wide; ocelli widely spaced; posterior width of ocellar triangle (WOT) 1.46 as long as ocello-ocular line (OOL); lateral side of ocellar triangle (LOT) 0.84 as long as WOT; anterior angle of ocellar triangle slightly less than $90^{\circ}$; frons shining, with dark setae in 2-4 longitudinal rows in addition to orbital setae, alutaceous, middle frons with engraved hexagonal or slightly irregular plates, in transverse direction ca. 8 plates $/ 0.1 \mathrm{~mm}$. Mandible 5-toothed, upper 2 teeth small and close together; apical margin of clypeus rounded, with a sharp median tooth. Maxillar palpi 6-segmented, labial palpi 3-segmented.

Mesosoma 2.16 as long as wide, 1.16 as wide as high. Pronotum 1.67 as wide as its disc anteriorly. Thoracic dorsum similarly sculptured as head; notauli short; propodeal disc 1.12 as long as wide behind spiracle, anteriorly with 5-7 weak, short discal carinae (ad $0.15 \mathrm{~mm})$; lateral carina weak, sublateral carina missing; transverse carina weak, missing medially; propodeal disc with elevated reticulate, ovoid sculpture.

Wings. Fore wing 2.4 as long as wide; subcosta with 10 dorsal setae; costa with 5-6 small setae on anterior margin; upper side of costal cell setose throughout, with 25 setae; stigma with 6 small setae near anterior margin and one short $(0.03 \mathrm{~mm})$ dorsal seta. Radius slightly curved, narrow, $0.82-0.87$ as long as basal vein. Basal and subbasal cells setose, setae small. Hind wing with 3 hamuli.

Legs. Fore femur 3.1 as long as wide; hind femur 3.16 as long as wide.

Metasoma. Gaster caudally pointed, 1.98 as long as wide, 1.24 as wide as high. Gaster broadest on posterior third of tergum 2. Penis: Fig. 6c, tergum 9: Fig. 7b, sternum 8: Fig. 7a, sternum 9: Fig. 7c.

Colour black; mandible reddish brown, with base infuscate; scape infuscate; pedicel reddish brown; flagellum and palpi dark brown; tegula and humeral plate brownish; wings hyaline, veins pale yellowish, stigma and anterior margin of subcosta pale brown; fore wing with brownish cloud on anterior, apical part beginning near stigma; coxae and femora blackish brown; trochanters, tibiae and tarsi brownish yellow, with mid- and hind tibiae mostly infuscate; gaster brownish black.

Measurements (in mm). Body 2.5; head 0.55; head width 0.58 ; frons width 0.35 ; eye $0.26 \times$ 0.21 ; distance of eye to occipital carina 0.17 ; malar space 0.07 ; WOT 0.22 ; POL 0.13 ; OOL 0.15 ; LOT 0.18; LOL 0.09; median ocellus: width 0.06 ; distance of lateral ocellus to occipital carina 0.09 ; scape 0.19 ; pedicel 0.086 ; flagellomere 1 : 0.094, 2: 0.10, and 3: 0.10; mesosoma 1.08 (width 0.50 ); notaulus $0.03-0.04$; median length of propodeal disc 0.46 ; fore wing 1.95 ; subcosta 0.65 ; basal vein 0.18 ; stigma 0.09 ; radius 0.15 0.16 ; hind femur 0.39 ; hind tibia 0.46 (width 0.07 ), inner spur 0.08 , outer spur 0.06 ; hind tarsus 0.54 , basitarsus 0.20 ; gaster 0.93 (width 0.47 ). Longest seta on temple 0.09 , on humeral plate 0.11 , and on lateral gaster 0.17 .

Variation of Swedish males $(n=4)$ : Body 2.5 (2.1-2.9). Fore wing 1.92 (1.64-2.10). Head width 0.56 (0.48-0.60), head 1.047 (1.04-1.05) as wide as long. Number of hair rows on frons 4.1 (2-6). Pterostigma with short dorsal seta, length $0.04(0.03-0.07)$. Radius $0.17(0.13-0.20)$ or $0.94(0.83-1.11)$ as long as basal vein. Subcosta with 10 (9-13) dorsal setae. Costa with 5.6 (3-7) setae on upper margin. Costal cell on upper surface with $30(23-40)$ setae. Notaulus short, length $0.024(0.0-0.04)$. 
Specimens examined (paratypes). Sweden, Sk.: Vittskövle, 14.VII.1974 1 +, 20.VII.1974 2 , , K.-J. Hedqvist leg. (NHRS); ÖG.: Sankta Anna, Tjärholm, 3.VIII.1956 1 \&, 8.VII.1957 1q, G. Wängsjö leg. (NHRS); Simonstorp, 3.VIII.1954 1 q, K.-J. Hedqvist leg. (NHRS); Nrk.: Örebro, Adolfsberg, 9.VIII.1973 1 \%, T. Nyholm leg. (NHRS); Sdm.: Nynäshamn, Vårdkasstigen, RN 16233/65349, 29.VI.2002 1 ๙ (indoors), J. Abenius leg. (JAPC). Upl.: Stockholm, Frescati, 27.V.1957 1 đ (at window), K.-J. Hedqvist leg. (NHRS); Vallentuna, 5.II.1970 1 ઈै (indoors), 11.VIII.1974 1 ㅇ, 26.VII.1975 1 ㅇ, 18.VI.1986 1 $\widehat{\jmath}$, K.-J. Hedqvist leg. (NHRS).

Biology. In Sweden several specimens have been taken indoors. Host is unknown. In Nynäshamn, at the home of J. Abenius, where several specimens have captured, also Reesa vespulae (Milliron) (Coleoptera, Dermestidae, Megatominae) was found (Johan Abenius, pers. comm.). Possibly it is a host for L. fumimarginalis.

Notes. The new species is close to the Central European species L. femoralis (Förster); possibly it represents a subspecies of that. It differs by its tendency to have the characteristic brownish infumation on the fore wing; this is stronger on the anterior part of the wing and begins basally near the stigma. Females of L. femoralis from Germany, the Netherlands, Belgium and France examined by Jeroen de Rond (pers. comm.) have entirely clear wings, as the neotype. The female with a strong infumation on the fore wings, taken on 11 August, 1974 in Vallentuna, and all three males taken by K.-J. Hedqvist were placed under Laelius anthrenivorus Trani, 1909 in coll. Hedqvist (NHRS). However, they do not fit to the original description of that species given by Trani (1909); e.g. the femora of the Swedish female are blackish but according to Trani the legs should be reddish yellow.

Laelius sp. (?L. utilis Cockerell, 1920), Figs. 3f, $8 \mathrm{a}$

Female from Arvika (Vrm.), Sweden. Length of body 2.8, of fore wing $1.65 \mathrm{~mm}$.

Description. Head 0.90 as wide as long; frons 1.29 as wide as eye long; distance from eye to occipital carina 0.67 as long as eye length; sides of head roundly convergent behind eyes to a straight

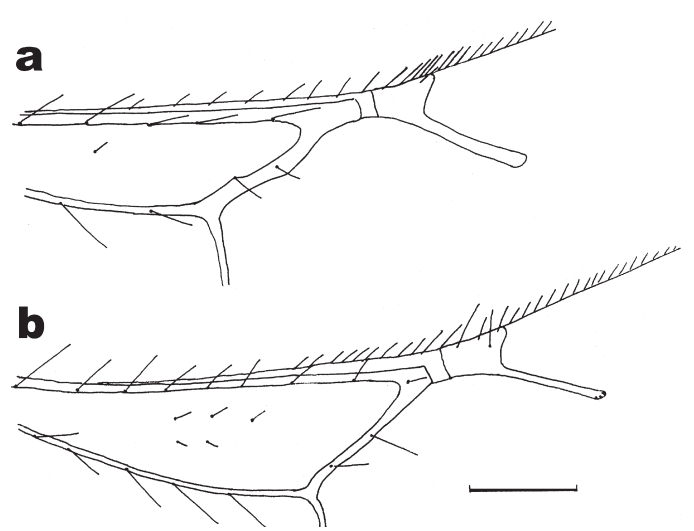

Fig. 8. Parts of fore wing of female of Laelius. - a. ?L. utilis Cockerell from Arvika, Sweden. - b. L. sp. from Saitama, Honshu, Japan. Scale $0.1 \mathrm{~mm}$.

vertex; first 5 antennal segments in a ratio of about 23:11:7:7:6, first flagellomere 1.1 as long as wide; ocelli small, widely spaced; posterior width of ocellar triangle (WOT) 1.04 as long as ocello-ocular line (OOL); lateral side of ocellar triangle (LOT) shorter (0.83) than WOT; anterior angle of ocellar triangle slightly less than $90^{\circ}$; frons shining, with dark setae in ca. 2 longitudinal rows in addition to orbital setae, alutaceous, middle frons with engraved hexagonal or slightly irregular plates, in transverse direction ca. 6 plates $/ 0.1 \mathrm{~mm}$. Mandible 5-toothed, upper 2 teeth small and close together; apical margin of clypeus rounded, with a median tooth. Maxillar palpi 6segmented, labial palpi 3-segmented.

Mesosoma 2.16 as long as wide, 1.28 as wide as high. Pronotum near tegulae 1.46 as wide as its disc anteriorly. Thoracic dorsum similarly sculptured as head; notauli linear, impressed, diverge anteriad; propodeal disc (Fig. 3f) medially 0.97 as long as wide behind spiracles, with complete median and transverse carinae, also with two rather long submedian carinae which extend $0.7-0.8$ to transverse carina, and 1-2 short carinae laterad of submedian carina; surface between submedian carinae with reticulate sculpture; lateral disc of propodeum posteriorly transversely striate; sublateral and lateral carinae present.

Wings. Fore wing 2.6 as long as wide; subcosta with 8 strong dorsal setae; costa with 4 small setae on anterior margin; basal cell with one seta; costal cell (Fig. 8a) apically with 12 setae; stigma with ca. 5 small setae near anterior margin, 
and short $(0.08 \mathrm{~mm})$ dorsal seta. Radius straight, narrow, $0.87-0.89$ as long as basal vein. Hind wing with 3 hamuli.

Legs. Fore femur 2.7 as long as wide; hind femur 2.8 as long as wide.

Metasoma. Gaster caudally pointed, 1.96 as long as wide, 1.17 as wide as high. Gaster broadest on posterior third of tergum 2; tergum 5 slightly incised medially.

Colour black; mandible, scape, and pedicel yellowish brown; flagellum dark brown, palpi brownish; tegula and humeral plate pale brown; fore wing with slight brownish infumation on apical part, more on anterior part beginning near stigma, veins pale yellowish, stigma and anterior margin of subcosta pale brown; coxae brown, slightly infuscate; legs otherwise reddish to yellowish brown, femora slightly infuscate; gaster brownish black, with apex reddish brown.

Measurements (in mm). Body 2.8; head 0.63; head width 0.57 ; frons width 0.35 ; eye $0.27 \times$ 0.20 ; distance of eye to occipital carina 0.18 ; malar space 0.11; WOT 0.19; POL 0.14; OOL 0.18 ; LOT 0.16; LOL 0.10; median ocellus: width 0.04; distance of lateral ocellus to occipital carina 0.07 ; scape 0.23 ; pedicel 0.11 ; flagellomere 1 : $0.07,2: 0.07$, and 3: 0.06; mesosoma 1.10 (width 0.51 ); notaulus $0.03-0.05$; median carina of propodeum 0.38 ; fore wing 1.65 ; subcosta 0.53 ; basal vein $0.11-0.12$; stigma 0.08 ; radius 0.10 ; hind femur 0.42 ; hind tibia 0.51 (width 0.08 ), inner spur 0.10 , outer spur 0.05 ; hind tarsus 0.55 , basitarsus 0.22 ; gaster 1.10 (width 0.56 ); median lengths of terga from base on $0.40,0.33,0.18$, $0.11,0.09,0.15$ and 0.06 ; ovipositor sheath visible dorsally $0.08 \times 0.07$. Longest seta on temple 0.13 , on humeral plate 0.13 , and on lateral gaster 0.17 .

Specimen examined. Sweden, Vrm.: Arvika, 28.VI.1955 1 ㅇ, ex Lyctus planicollis, import av yxskaft U.S.A., K.-J. Hedqvist leg. (NHRS).

Comments. The female was reported from Sweden as Laelius utilis Cockerell by Hedqvist (1975): "reared from an axe-handle imported from U.S.A. and infested by Lyctus brunneus Steph. (Col., Lyctidae)". The female resembles much a small female of $L$. fumimarginalis but its legs are paler, scape is paler, hardly infuscate, flagellomere 1 is almost quadrate, and radius/basal vein index higher. It fits rather well to the original description of Laelius utilis Cockerell, 1920 and the descriptions of L. utilis in Evans (1978) and Mertins (1985). However, there are several morphological differentiating characters between the Swedish female and the females of $L$. pedatus, so it is difficult to agree with Mertins (1985) that there are no firm differences between $L$. utilis and L. pedatus. Or perhaps the Swedish female is not L. utilis? A comparison with N. American specimens of L. utilis was not possible, because the loan requests to the museums in Iowa and Washington, D.C. remained without an answer.

Laelius parcepilosus Vikberg sp. n. Figs. 4b, d, 9a-b, 10a, 11a-b, 12a

Holotype female labelled Fennia [= Finland], Ta: Pälkäne, [Grid 27E] 679:36, 7.VIII.1977, leg. E. Valkeila, coll. Erkki Valkeila (DABH).

Description. Female holotype. Length of body 3.3 , of fore wing $1.85 \mathrm{~mm}$.

Head (Fig. 9a) 0.95 as wide as long; frons 1.6 as wide as eye long; distance from eye to occipital carina 0.63 as long as eye length; sides of head roundly convergent behind eyes to a straight vertex; first 5 antennal segments in a ratio of about 25:14:8:9:9, first flagellomere 1.18 as long as wide; ocelli small, widely spaced; posterior width of ocellar triangle (WOT) 1.26 as long as ocelloocular line $(\mathrm{OOL})$; lateral side of ocellar triangle (LOT) shorter (0.86) than WOT; anterior angle of ocellar triangle slightly less than $90^{\circ}$ (Fig. 4d); frons shining, with dark setae in ca. 2 longitudinal rows in addition to orbital setae, alutaceous, middle frons with engraved hexagonal or slightly irregular plates, in transverse direction ca. 6 plates $/ 0.1 \mathrm{~mm}$. Mandible 5-toothed, upper 2 teeth small and close together; apical margin of clypeus rounded, with a median tooth. Maxillary palpi 6segmented, labial palpi 3-segmented.

Mesosoma 1.87 as long as wide, 1.4 as wide as high. Pronotum near tegulae 1.7 as wide its disc anteriorly. Thoracic dorsum similarly sculptured as head; notauli linear, strong, diverge anteriad; propodeal disc (Fig. 10a) medially 0.96 as long as wide behind spiracles, with complete median and transverse carinae, also with two rather long submedian carinae which extend 0.70.8 to transverse carina, and a short carina laterad of submedian carina (= altogether 5 discal 


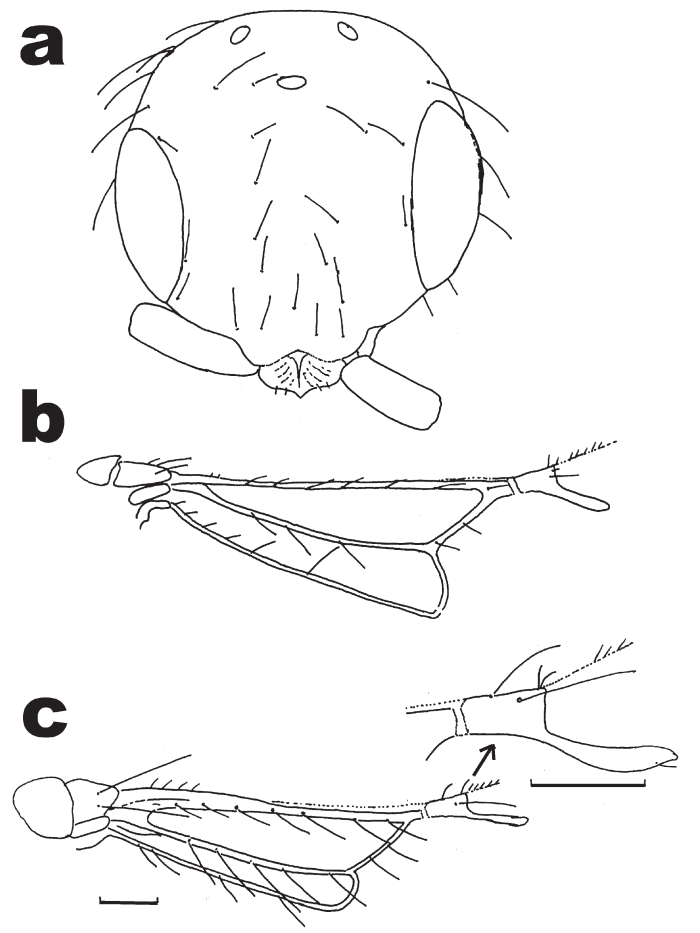

Fig. 9. Body parts of Laelius. - a-b. L. parcepilosus Vikberg, sp. n., holotype female; head in anterior view (a); part of fore wing (b). - c. L. pedatus (Say), female from Madison, Wisconsin, part of fore wing, with pterostigma and radial vein in larger scale. Scale 0.1 $\mathrm{mm}$.

carinae); surface between submedian carinae with wrinkled transverse striae, small areolae transverse, shining; disc of propodeum laterally transversely striate; sublateral and lateral carinae strong.

Wings. Fore wing 2.7 as long as wide; subcosta (Fig. 9b) with 7-8 strong dorsal setae; costa with 2 very small setae on anterodorsal margin; basal cell and subbasal cell glabrous; Upper surface of costal cell (Fig. 4b) apically without setae (on ventral surface 1-2 setae near pterostigma); stigma with 3 small setae near anterior margin and one short $(0.07 \mathrm{~mm})$ dorsal seta. Radius short, slightly curved, in apical half slightly broadened, 0.81 as long as basal vein. Hind wing with 3 hamuli.

Legs. Fore femur 2.8 as long as wide; hind femur 2.67 as long as wide.

Metasoma. Gaster caudally pointed, 1.85 as long as wide, 1.3 as wide as high. Gaster broadest on posterior third of tergum 2; tergum 5 slightly incised medially.

Colour black; mandible yellowish brown to red, with base infuscate; scape, pedicel reddish yellow; flagellum pale brown, and palpi dark brown; tegula and humeral plate brown; wings clear hyaline, veins pale yellowish, stigma and anterior margin of subcosta pale brown; fore and mid-coxae blackish brown, and hind coxa brownish black; trochanters, tibiae and tarsi yellowish brown; legs otherwise yellowish brown, all femora broadly infuscate; gaster brownish black, with apex reddish brown.

Measurements (in mm). Body 3.3; head 0.69; head width 0.65 ; frons width 0.40 ; eye $0.32 \times$ 0.25 ; distance of eye to occipital carina 0.20 ; malar space 0.11 ; WOT 0.22 ; POL 0.15 ; OOL 0.18 ; LOT 0.20; LOL 0.12; median ocellus: width 0.05 ; distance of lateral ocellus to occipital carina 0.09 ; scape 0.25 ; pedicel 0.14 ; flagellomere 1 : 0.08, 2: 0.09, and 3: 0.09; mesosoma 1.27 (width 0.68 ); notaulus $0.10-0.11$; median carina of propodeum 0.44 ; fore wing 1.85 ; subcosta 0.62 ; basal vein 0.13 ; stigma 0.07 ; radius $0.10-0.11$; hind femur 0.48; hind tibia 0.60 , inner spur 0.11 , outer spur 0.06 ; hind tarsus 0.65 ; gaster 1.35 (width 0.73 ); median lengths of terga from base on $0.50,0.35,0.30,0.18,0.12,0.15$ and 0.05 ; ovipositor sheath visible dorsally $0.10 \times 0.07$. Longest seta on temple 0.15 , on humeral plate 0.10 , and on lateral metasoma 0.21 .

Variation of Finnish females $(n=6)$ : Body 2.8-3.1. Fore wing 1.78 (1.67-1.86). Head width $0.62(0.58-0.65)$, head $0.96(0.94-0.98)$ as wide as long. Dorsal seta of pterostigma 0.06-0.08. Radius $0.105(0.10-0.12)$ or $0.81(0.76-0.89)$ as long as basal vein. Subcosta with 5-7 dorsal setae, costa with $2.1(1-3 ; n=12)$ small dorsal setae; costal cell with $1.3(0-3 ; n=12)$ small dorsal setae; basal cell glabrous $(n=12)$. Notaulus linear, impressed, length $0.07(0.04-0.10 ; n=$ 12).

Male. Paratype from Mikkeli (Sa), Finland. Length of body 2.4, of fore wing $1.93 \mathrm{~mm}$.

Head 1.05 as wide as long; frons 1.43 as wide as eye long; distance from eye to occipital carina 0.63 as long as eye length; sides of head roundly convergent behind eyes to a straight vertex; first 5 antennal segments in a ratio of about 20:11:8: 10:10, first flagellomere 1.5 as long as wide; 

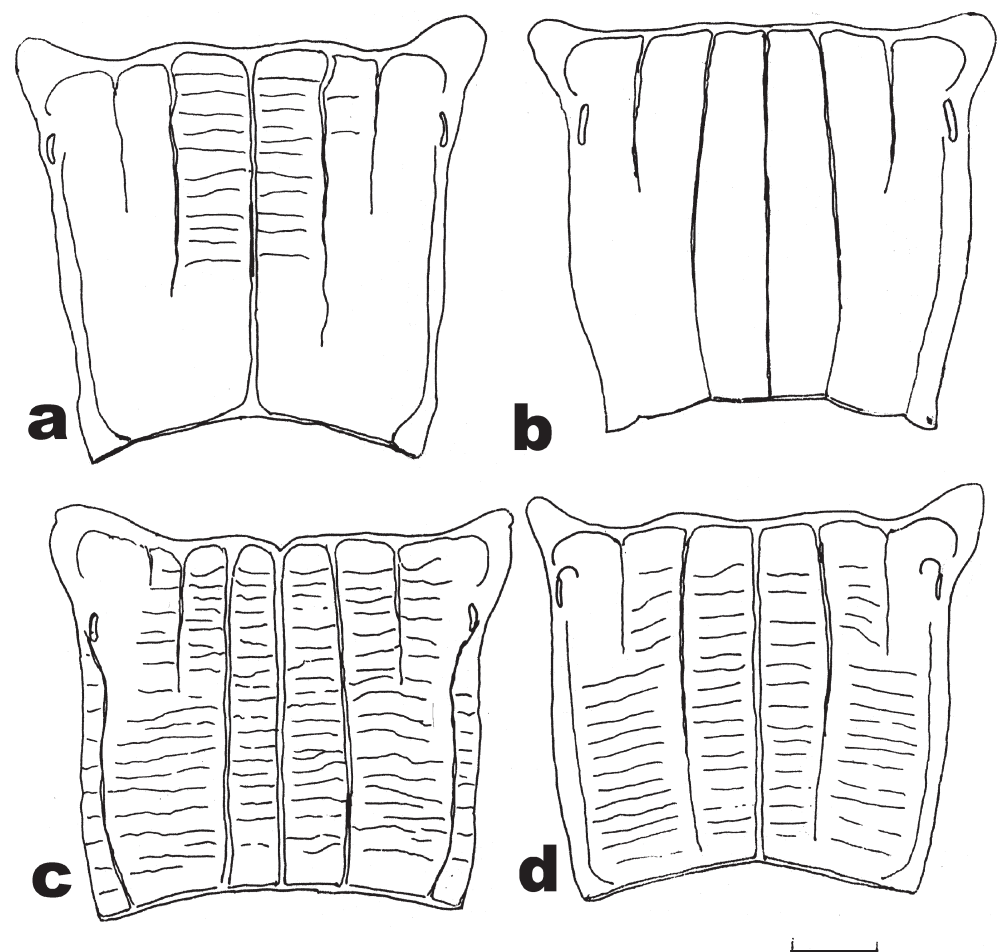

Fig. 10. Propodeal discs of females of Laelius. - a. L. parcepilosus Vikberg, sp. $\mathrm{n}$., holotype. - b. L. pedatus (Say), from Oulu, Finland. c. L. seticornis (Duchaussoy) from La Palma. - d. L. sp. from Saitama, Honshu, Japan. Scale $0.1 \mathrm{~mm}$. ocelli widely spaced; posterior width of ocellar triangle (WOT) 1.43 as long as ocello-ocular line (OOL); lateral side of ocellar triangle (LOT) shorter (0.84) than WOT; anterior angle of ocellar triangle slightly less than $90^{\circ}$; frons shining, with dark setae in 6-7 longitudinal rows in addition to orbital setae, alutaceous, middle frons with engraved hexagonal or slightly irregular plates, in transverse direction $8-9$ plates $/ 0.1 \mathrm{~mm}$. Mandible 5-toothed, upper 2 teeth small and close together; apical margin of clypeus rounded, with a sharp median tooth. Maxillar palpi 6-segmented, labial palpi 3-segmented.

Mesosoma 2.1 as long as wide, 1.16 as wide as high. Pronotum 1.7 as wide as its disc anteriorly. Thoracic dorsum similarly sculptured as head; notauli linear, posteriorly stronger, diverging anteriad, anteriorly indicated by dense, small alutaceous sculpture; propodeal disc medially 1.08 as long as wide behind spiracle, anteriorly with weak and short median carina; laterad of median carina one to two short, weak and wrinkled carinae on both sides; lateral and transverse carinae distinct; propodeal disc medially with elevated reticulate, ovoid sculpture, laterally transversely striate.
Wings. Fore wing 2.4 as long as wide; subcosta with 11 dorsal setae; costa with 5-6 small setae on upper anterior margin; upper side of costal cell setose throughout, with 28 setae; stigma with 6 small setae near anterior margin and one short $(0.05 \mathrm{~mm})$ dorsal seta. Radius $1.04-1.10$ as long as basal vein, slightly curved, almost equally broad. Basal and subbasal cells setose, setae small. Hind wing with 3 hamuli.

Legs. Fore femur 3.4 as long as wide; hind femur 3.45 as long as wide.

Metasoma. Gaster caudally pointed, 1.95 as long as wide, 1.25 as wide as high. Gaster broadest on posterior third of tergum 2. Terga 8-9: Fig. 11a, sterna 8-9: Fig. 11b, penis: Fig. 12a.

Measurements (in mm). Body 2.4; head 0.535 ; head width 0.56 ; frons width 0.34 ; eye $0.24 \times 0.20$; distance of eye to occipital carina 0.15 ; malar space 0.08 ; WOT 0.21 ; POL 0.13 ; OOL 0.15; LOT 0.18; LOL 0.09; median ocellus: width 0.05 ; distance of lateral ocellus to occipital carina 0.10 ; scape 0.20 ; pedicel 0.11 ; flagellomere 1: 0.08, 2: 0.10, and 3: 0.10; mesosoma 1.06 (width 0.50 ); notaulus $0.05-0.06$; median length of propodeal disc 0.39 ; fore wing 1.93 ; subcosta 0.67 ; basal vein 0.18 ; stigma 0.09 ; radius $0.18-$ 


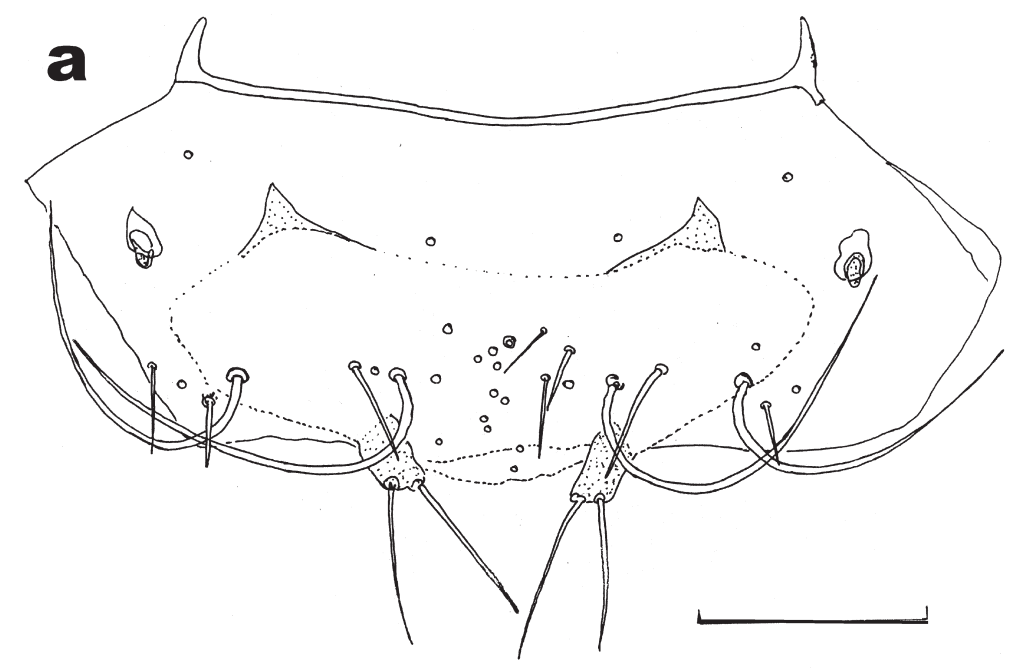

Fig. 11. Paratype male of Laelius parcepilosus Vikberg, sp. n. from Mikkeli. -a. Terga 8 and 9 , with pygostyles. - b. Sterna 8 and 9. Scale $0.1 \mathrm{~mm}$.

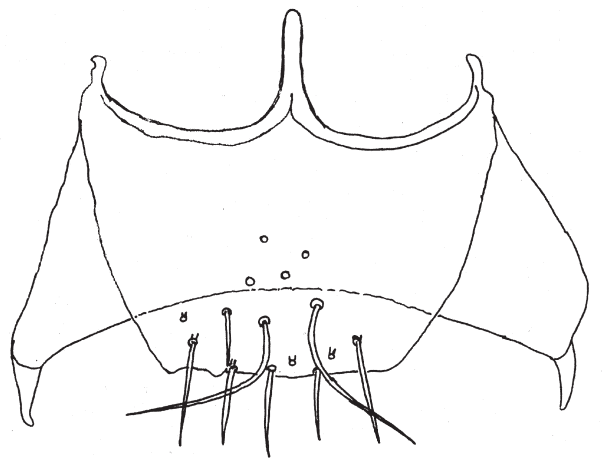

0.19 ; hind femur 0.38 ; hind tibia 0.42 , inner spur 0.10 , outer spur 0.06 ; hind tarsus 0.50 ; metasoma (ventrally) 1.06; gaster 0.88 (width 0.45 ). Longest seta behind eye 0.10 , on humeral plate 0.10 , and lateral metasoma 0.18 .

Paratypes. Finland, Ta: Hämeenlinna (676:36), 20.VI.1975 1 q, 30.VIII.1975 1 ㅇ, 26.VI.1976 1 q, E. Valkeila leg. (DABH). Sa: Mikkeli (Mikkelin mlk., 6830:501), 23.VI.1984 1 §ิ, 24.VI.1988 1 , M. Koponen leg. (DABH). Kl: Parikkala [682:63], 2.VII.1963 1 +, E. Valkeila leg. (DABH).

Biology. The holotype female was captured on a wall of an old log cottage. The female from Mikkeli in 1988 was captured on a wall of a woodshed. Host is unknown. A possible host is Megatoma undata (Linnaeus) that is often found on the walls of the log cottages.

Etymology. The specific name is derived from the Latin words parcus which means sparse, and pilosus, hairy. The upper frons of the female has few hairs which are arranged into two longitudinal rows, beside the orbital setae.

Laelius pedatus (Say, 1836) Figs. 9c, 10b, 12b, $13 \mathrm{a}-\mathrm{c}, 14$

Female from Oulu (Obo), Finland (29.IV. 1995). Length of body 3.1 , of fore wing $1.70 \mathrm{~mm}$.

Description. Head 0.91 as wide as long; frons 1.58 as wide as eye long; distance from eye to occipital carina 0.88 as long as eye length; sides of head roundly convergent behind eyes to a straight vertex; first 5 antennal segments in a ratio of about 26:15:10:10:10; first flagellomere 1.5 as long as wide; ocelli small, widely spaced; posterior width of ocellar triangle (WOT) 0.85 as long as ocello-ocular line (OOL); lateral side of ocellar triangle (LOT) shorter (0.84) than WOT; anterior angle of ocellar triangle slightly less than $90^{\circ}$; frons shining, with dark setae in ca. 8 longitudinal rows in addition to orbital setae, alutaceous, middle frons with engraved hexagonal or slightly ir- 

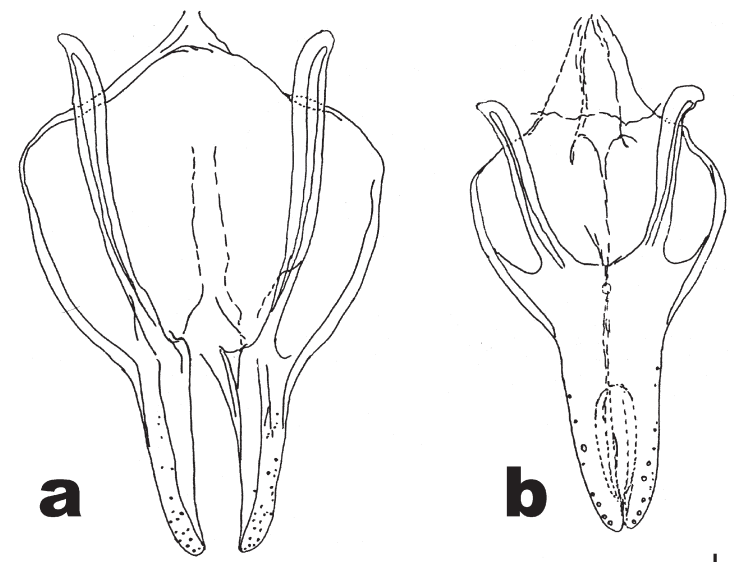

Fig. 12. Penis of Laelius in ventral view. - a. $L$. parcepilosus Vikberg, sp. n., paratype from Mikkeli, Finland. - b. L. pedatus (Say), from Oulu, Finland - c. L. sp. from Black See coast, Bulgaria. Scale $0.1 \mathrm{~mm}$. regular plates, in transverse direction ca. 8 plates $/ 0.1 \mathrm{~mm}$. Mandible 5-toothed, upper 2 teeth small and close together; apical margin of clypeus rounded, with a median tooth. Maxillary palpi 6segmented, labial palpi 3-segmented.

Mesosoma 2.17 as long as wide, 1.06 as wide as high. Pronotum near tegulae 1.66 as wide its disc anteriorly. Thoracic dorsum similarly sculptured as head; notauli short, round, puncture-like; propodeal disc (Fig. 10b) medially 0.98 as long as wide behind spiracles, with complete median and transverse carinae, with two strong submedian carinae which extend to transverse carina, and a short carina laterad of submedian carina (= altogether 5 discal carinae); submedian carinae almost parallel, their distance anteriorly 0.13 , in the middle 0.15 and on transverse carina $0.14 \mathrm{~mm}$; surface between submedian carinae with wrinkled transverse striae and reticulate sculpture, small areolae transverse to ovoid, shining; disc of propodeum laterally transversely striate; sublateral and lateral carinae strong.

Wings. Fore wing 2.6 as long as wide; subcosta (similar as in Fig. 9c) with 7-8 strong dorsal setae; costa with 4 small setae on anterior margin; basal cell and subbasal cell glabrous; costal cell apically without setae; stigma with 2-4 small setae near anterior margin and one or two longer (ad $0.10 \mathrm{~mm}$ ) dorsal setae. Radius short, slightly curved, in apical half broadened, 0.85 as long as basal vein. Hind wing with 3 hamuli.

Legs. Fore femur 3.16 as long as wide; hind femur 3.2 as long as wide.

Metasoma. Gaster caudally pointed, 1.98 as long as wide, 1.24 as wide as high. Gaster broad- est on posterior third of tergum 2; caudal margin of tergum 5 slightly incised medially.

Colour black; mandible yellowish brown, with base infuscate; scape and pedicel yellowish brown; flagellum and palpi dark brown; tegula and humeral plate brown; wings clear hyaline, apical half with fumose cloud which is divided by folds of obliterated veins into 3-4 parts; veins pale yellowish, anterior margin of subcosta pale brown; coxae brownish black; legs otherwise yellowish brown, with mid- and hind femora very slightly infuscate; gaster black.

Measurements (in mm). Body 3.1; head 0.67; head width 0.61 ; frons width 0.41 ; eye $0.26 \times$ 0.20 ; distance of eye to occipital carina 0.23 ; malar space 0.12 ; WOT 0.19; POL 0.12; OOL 0.22; LOT 0.16; LOL 0.08; median ocellus: width 0.05 ; distance of lateral ocellus to occipital carina 0.08 ; scape 0.26 ; pedicel 0.15 ; flagellomere 1 : $0.10,2: 0.10$, and 3: 0.10 ; mesosoma 1.15 (width 0.53 ); notaulus $0.01-0.02$; median carina of propodeum 0.44 ; fore wing 1.70 ; subcosta 0.52 ; basal vein 0.13 ; stigma 0.08 ; radius 0.11 ; hind femur 0.48 ; hind tibia 0.57 , inner spur 0.11 , outer spur 0.07; hind tarsus 0.65; gaster 1.25 (width 0.63 ); median lengths of terga from base on 0.48 , $0.35,0.20,0.17,0.10,0.15$ and 0.04 ; ovipositor sheath visible dorsally $0.07 \times 0.07$. Longest seta on temple 0.20 , on humeral plate 0.14 , and on lateral metasoma 0.23 .

Variation of Finnish females $(n=9)$ : Body 2.45-3.1. Fore wing 1.60 (1.44-1.74). Head width $0.56(0.49-0.61)$, head $0.88(0.86-0.90)$ as wide as long. Dorsal seta of pterostigma 0.11 (0.07-0.14). Radius short: $0.10(0.08-0.11)$. 


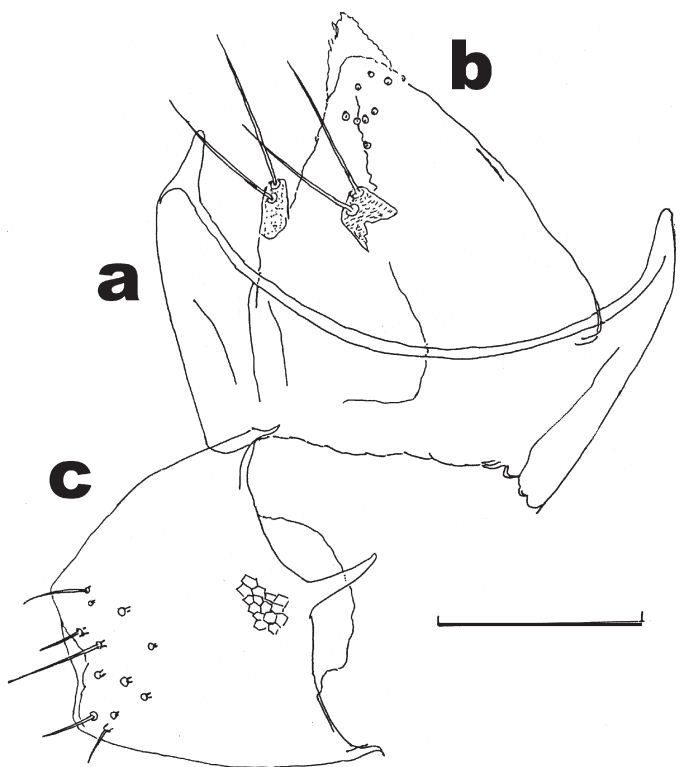

Fig. 13. Male of Laelius pedatus (Say), from Oulu, Finland. - a. Sternum 8. - b. Tergum 9, with pygostyles. c. Sternum 9. Scale $0.1 \mathrm{~mm}$.

Male from Oulu, Finland (reared from Reesa vespulae). Length of body 2.9, of fore wing 2.19 $\mathrm{mm}$.

Description, male. Head 0.98 as wide as long; frons 1.58 as wide as eye long; distance from eye to occipital carina 0.81 as long as eye length; sides of head roundly convergent behind eyes to a straight vertex; first 5 antennal segments in a ratio of about 23:10:12:15:13, first flagellomere 2.2 as long as wide; ocelli widely spaced; posterior width of ocellar triangle (WOT) 1.08 as long as ocello-ocular line (OOL); lateral side of ocellar triangle (LOT) shorter (0.94) than WOT; anterior angle of ocellar triangle slightly less than $90^{\circ}$; frons shining, with dark setae in 9-10 longitudinal rows in addition to orbital setae, alutaceous, middle frons with engraved hexagonal or slightly irregular plates, in transverse direction 8 plates $/ 0.1 \mathrm{~mm}$. Mandible 5-toothed, upper 2 teeth small and close together; apical margin of clypeus rounded, with a sharp median tooth. Maxillary palpi 6-segmented, labial palpi 3-segmented.

Mesosoma 2.0 as long as wide, 1.23 as wide as high. Pronotum 1.76 as wide as its disc anteriorly. Thoracic dorsum similarly sculptured as head; notauli linear, impressed; propodeal disc medially 1.04 as long as wide behind spiracles,

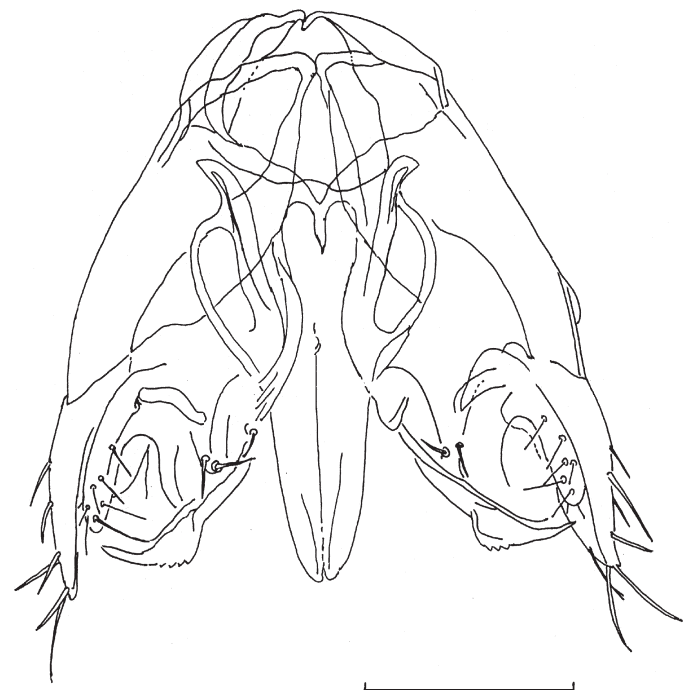

Fig. 14. Male genitalia in ventral view of Laelius pedatus (Say), from Oulu, Finland. Scale $0.1 \mathrm{~mm}$.

anteriorly with 5 weak carinae; median and submedian carinae extend 0.64 of distance to transverse carina; lateral and transverse carinae distinct; propodeal disc medially with elevated reticulate, ovoid sculpture, laterally transversely striate.

Wings. Fore wing 2.4 as long as wide; subcosta with 11 strong dorsal setae; costa with 4 small setae; anterior margin of costal cell with 14 setae, basal third glabrous; stigma with 4 small setae near anterior margin and one $(0.09 \mathrm{~mm})$ dorsal seta. Radius slightly curved, apical half dilated posteriorly. Basal and subbasal cells with some small setae. Hind wing with 3 hamuli.

Legs. Fore femur 3.6 as long as wide; hind femur 3.76 as long as wide.

Metasoma. Gaster caudally pointed, 1.86 as long as wide, 1.38 as wide as high. Gaster broadest on posterior third of tergum 2. Genitalia: Fig. 14, penis: Fig. 12b, sterna 8-9: Figs 13a, 13c, tergum 9: Fig. 13 b.

Colour black; mandible yellowish brown, with base infuscate; scape and pedicel yellowish brown, scape basally infuscate; flagellum and palpi dark brown; tegula and humeral plate brown; wings clear hyaline, apical half with faint infumation; veins pale yellowish, anterior margin of subcosta pale brown; coxae black; legs otherwise yellowish brown, with femora infuscate and 
mid- and hind tibiae very slightly infuscate; gaster black.

Measurements (in mm). Body 2.9; head 0.64; head width 0.63 ; frons width 0.41 ; eye $0.26 \times$ 0.21 ; distance of eye to occipital carina 0.21 ; malar space 0.09 ; WOT 0.21 ; POL 0.11 ; OOL 0.19; LOT 0.20; LOL 0.08; median ocellus: width 0.07; distance of lateral ocellus to occipital carina 0.11 ; scape 0.23 ; pedicel 0.10 ; flagellomere 1 : $0.12,2: 0.15$, and 3: 0.13 ; mesosoma 1.18 (width $0.60)$; notaulus $0.05-0.06$; median length of propodeal disc 0.47 ; fore wing 2.19 ; costa 0.12 ; subcosta 0.65 ; basal vein 0.20 ; stigma 0.08 ; radius 0.16 ; hind femur 0.49 ; hind tibia 0.58 , inner spur 0.11, outer spur 0.08; hind tarsus 0.67; metasoma (ventrally) 1.18; gaster 1.08 (width 0.58 ); medial lengths of terga from base on 0.45 , $0.34,0.18,0.12,0.08,0.10$, and 0.05 . Longest seta on temple 0.17 , on humeral plate 0.16 , and on lateral gaster 0.26 .

Variation of Finnish males $(n=18)$ : Body 2.4 (1.75-2.9). Fore wing 1.93 (1.47-2.20). Head width $0.53(0.42-0.63)$, head $0.96(0.93-0.98)$ as wide as long. Dorsal seta of stigma 0.08 (0.030.10). Radius 0.14 (0.09-0.16).

Paratypes. Finland, N: Helsinki (6681:390), 11.I.1993 1 ふ, 15.I.1993 1 ふૈ, 29.I.1993 1 ふ,, 29.I.1996 1 ふૈ, 2.X.1998 1 ㅇ, M. Koponen leg. (DABH); V.1996 1 o, M. Heidemaa leg. (DABH); Vantaa (Louhela, 668:38), 8.XII.1987 1 ふૈ, 18.XII.1987 2 q, J. Stenroos leg. (DABH). Ka: Kotka (670:49), 15.XI.1997 1 ふ, 15.XII.1997 1 , E. Valleala leg. (VVPC). Kn: Kuhmo (7120:620), 28.I.2001 1 ठ઼, 6.II.2001 1 ठ 1 +, G. Várkonyi leg. (KUHMO). Obo: Oulu (Linnanmaa 721:42), 3.III.1995 1 ô, 27.III.1995 1 đ̂, 29.IV.1995 1 q, G. Várkonyi leg. (OULU); ex "pupa", Reesa vespulae, 19967 § 1 ㅇ, V. Karhula leg. (OULU); 2.I.1996 1 ㅇ, A. Itämies leg. (OULU); 3.II.1997 1 §ૈ, G. Várkonyi leg. (OULU).

Biology. The species was listed by Söderman \& Vikberg (2003) from Finland, where it occurs only indoors. It has been captured in five localities. At the Department of Applied Biology, the University of Helsinki the specimens have been captured in the rooms of entomological collections where larvae of Reesa vespulae (Milliron) (Dermestidae) have been harmful. In the Zoolog- ical Museum, the University of Oulu, the species was also associated with Reesa vespulae, and seven males and one female have been labelled: "ex pupa, host: Reesa vespulae". The species has also been captured in Kotka (Einari Valleala, pers. comm.) and Kuhmo (Gergely Várkonyi, pers. comm.) inside a room where Reesa vespulae also occurred. Reesa vespulae appears to be a new host for Laelius pedatus.

Comments. Using the keys in Evans (1978: 184), the Finnish females run to L. pedatus (Say), because their legs are rufotestaceous beyond the coxae, and the Finnish males run in couplet 4 either to L. pedatus ("legs rufotestaceous to strawcoloured beyond coxae") or L. utilis Cockerell ("femora fuscous"). Their separation can be difficult because of the lack of separating morphological characters (Mertins 1985). Mertins gave some colour characters which could help distinguish between these two species.

The Finnish specimens are not easy to separate using the characters in table 1 of Mertins (1985), because the colour characters vary, and some fit better to L. pedatus, while others better to L. utilis. The larger Finnish specimens are very similar to the specimens of the Amsterdam strain of $L$. pedatus, and surely represent the same species. Evans (1978) described both sexes of North American species, and there appears to be a difference in the shape of antennal segment 3 or flagellomere 1. Evans measured one female and one male of all species and he gave following values for L. pedatus: segment three $1.5 \mathrm{x}$ ( $($ ) or 1.7 $\mathrm{x}\left(\oslash^{\Uparrow}\right)$ as long as wide, and for L. utilis: $1.2 \mathrm{x}($ ( $)$ or $1.3 \mathrm{x}(\widehat{\bigcirc})$ as long as wide.

The measurement of the specimens originating from Madison, Wisconsin, U. S. A. (Fig. 9c; part of fore wing), and Amsterdam, the Netherlands, and 5 localities from Finland gave following results of length/width index of flagellomere 1: Madison, 1.5 (one female); Amsterdam, 1.73 (1.67-1.8; 3 ㅇ), 2.34 (2.15-2.44; 4 §); and Finland, 1.61 (1.5-1.75; 8 ㅇ), $2.26(2.0-2.5 ; 10$ ○). The values of the females from three countries all agree with L. pedatus of Evans (1978). The values of males from the Netherlands and Finland are even higher than Evans (1978) gave, and thus they fit better to L. pedatus, but they do not fit to L. utilis at all. 


\subsection{Redecription of the female of Laelius seticornis (Duchaussoy, 1916) (Fig. 10c)}

A female of Laelius, resembling L. pedatus, was captured in the Canary Islands, La Palma, El Paso, Cumbre Nueva (850-1,000 m a.s.1.) on 28.II.1997 (M. Koponen leg., DABH). From the Canary Islands, two species of Laelius, viz. Allepyris seticornis and A. mesitioides, have earlier been described from Teneriffe (Duchaussoy 1916). A. seticornis was described based on one specimen (sex unspecified), and $A$. mesitioides based on one male. Gordh (in Gordh \& Móczár 1990) noted that $A$. seticornis may be the female of $A$. mesitioides, and their types are probably lost. The female from La Palma agrees well with the original description of Allepyris seticornis, and Laelius seticornis (Duchaussoy) is redescribed below on the basis of this female. Later it could be designated as a neotype of the species, if the holotype is really lost.

Female from La Palma. Length of body 2.9, of fore wing $1.65 \mathrm{~mm}$.

Description. Head 0.95 as wide as long; frons 1.48 as wide as eye long; distance from eye to occipital carina 0.78 as long as eye length; sides of head straightly convergent behind eyes and then rather abrubtly rounded to an almost straight vertex; first 5 antennal segments in a ratio of about 24:14:9:9:9; first flagellomere 1.5 as long as wide; ocelli small, widely spaced; posterior width of ocellar triangle (WOT) 0.90 as long as ocelloocular line (OOL); lateral side of ocellar triangle (LOT) shorter (0.87) than WOT; anterior angle of ocellar triangle slightly less than $90^{\circ}$; frons shining, with dark setae in ca. 7 longitudinal rows in addition to orbital setae, alutaceous, middle frons with engraved hexagonal or slightly irregular plates, in transverse direction ca. 7 plates $/ 0.1 \mathrm{~mm}$. Mandible 5-toothed, upper 3 teeth small and close together; apical margin of clypeus rounded, with a median tooth. Maxillary palpi 6-segmented, labial palpi 3 segmented.

Mesosoma 2.3 as long as wide, 1.14 as wide as high. Pronotum near tegulae 1.43 as wide its disc anteriorly. Thoracic dorsum similarly sculptured as head; notauli short, linear, impressed, diverging anteriad; propodeal disc (Fig. 10c) medially 0.93 as long as wide behind spiracles, with complete median and transverse carinae, with two strong submedian carinae which extend to transverse carina, and a short carina laterad of submedian carina (= altogether 5 discal carinae); submedian carinae almost parallel, their distance anteriorly 0.11 , behind middle 0.14 and on transverse carina $0.13 \mathrm{~mm}$; surface between submedian carinae with wrinkled transverse striae, shining; disc of propodeum laterally transversely striate; sublateral and lateral carinae strong.

Wings. Fore wing 1.83 as long as wide; subcosta with 6 strong dorsal setae; costa with 3 small setae on anterior margin; basal cell glabrous, subbasal cell with many tiny brown spots; costal cell apically without setae or with one seta; stigma with 2-3 small setae near anterior margin and one long (ad $0.14 \mathrm{~mm}$ ) dorsal seta. Radius short, slightly curved, in apical half broadened, 0.85 as long as basal vein. Hind wing with 3 hamuli.

Legs. Fore femur 3.07 as long as wide; hind femur 3.27 as long as wide.

Metasoma. Gaster caudally pointed, 1.77 as long as wide, 1.23 as wide as high. Gaster broadest on posterior third of tergum 2; caudal margin of tergum 5 slightly incised medially.

Colour black; mandible reddish brown, with base infuscate; scape and pedicel reddish brown; flagellum and palpi dark brown; tegula and humeral plate yellowish brown; wings hyaline, apical half with brownish cloud which is divided by pale folds of obliterated veins into 3-4 parts; veins pale yellowish, anterior margin of subcosta pale brown; coxae brownish black; femora and tibiae reddish yellow, tarsi yellowish brown.

Measurements (in mm). Body 2.9; head 0.65; head width 0.62 ; frons width 0.40 ; eye $0.27 \times$ 0.21 ; distance of eye to occipital carina 0.21 ; malar space 0.13 ; WOT 0.20 ; POL 0.11 ; OOL 0.22 ; LOT 0.17 ; median ocellus: width 0.05 ; distance of lateral ocellus to occipital carina 0.08 ; scape 0.24; pedicel 0.14; flagellomere 1: 0.09, 2: 0.09 , and 3: 0.09; mesosoma 1.15 (width 0.50 ); notaulus 0.06 ; median carina of propodeum 0.41 ; fore wing 1.65 ; subcosta 0.53 ; basal vein 0.12 ; stigma 0.07 ; radius 0.10 ; fore femur 0.46 ; hind femur 0.49 ; hind tibia 0.55 , inner spur 0.10 , outer spur 0.06; hind tarsus 0.59; gaster 1.15 (width 0.65 ); median lengths of terga from base on 0.47 , $0.34,0.21,0.08,0.09,0.14$ and 0.04 ; ovipositor sheath visible dorsally $0.10 \times 0.07$. Longest seta 
on temple 0.17 , on humeral plate 0.16 , and on lateral metasoma 0.21 .

Male. Not examined. Probably Allepyris mesitioides represents the male of L. seticornis but the holotype may be lost. The antenna of the male (Duchaussoy 1916; fig. 1, I) resembles much that of L. pedatus.

Notes. The female closely resembles that of $L$. pedatus but differs most clearly on the structure of propodeum that is parallel behind spiracles and has stronger-wrinkled sculpture on disc with almost lacking reticulate sculpture.

\subsection{Notes on two unidentified species of Laelius, from Japan and Bulgaria}

Iwata (1941) and Yamada (1955) reported from Japan, as a parasite of Anthrenus verba[s]ci Linné, a species that they called Allepyris microneurus. However, the legs, except coxae, of the Japanese specimens are yellowish brown. They represent another species; Dr. Mamoru Terayama (pers. comm.) will in the future describe it as a new species. The first author was able to examine three females from Dr. Terayama's private collection (MTPC). One further female was found in $\mathrm{MZH}$; it has been collected in Japan, Honshu, Tokyo on 29.X.1954 by P. Savolainen (FMNH). Some characters of the female from Honshu, Saitama, Ogose, 16.VII.1979, T. Nambu leg. (MTPC) are given: Length of body $2.8 \mathrm{~mm}$, head width $0.62 \mathrm{~mm}$. Costal cell (Fig. 8b) apically with 9 setae. Propodeal disc (Fig. 10d) medially 0.87 as long as wide behind spiracles, with complete median and transverse carinae, with two strong submedian carinae which extend almost to transverse carina, and a short carina laterad of submedian carina (= altogether 5 discal carinae); submedian carinae almost parallel, their distance anteriorly 0.14 , behind middle 0.15 and on transverse carina $0.14 \mathrm{~mm}$; surface between submedian carinae with transverse striae, shining; disc of propodeum laterally transversely striate; sublateral carina rather weak.

The Japanese species seems to be closely related to $L$. elisae Russo and obviously also to $L$. fulvipes Kieffer. It is not conspecific with any species occurring in Northern Europe.

Two males of another Laelius were studied from the the Black See coast of Bulgaria, captured VIII-IX.1992, Kornmilch leg. (CKPC). The larger male is $2.4 \mathrm{~mm}$ long, with head width $0.53 \mathrm{~mm}$. Legs brownish yellow, with coxae infuscate. Penis: (Fig. 12c). This seems to be the first record of a Laelius from Bulgaria. It is not possible to identify the species before the female is captured and compared with the species which have brownish yellow legs, except coxae.

\subsection{Keys to the females and males of Finnish and Swedish and some other examined Palaearctic species of Laelius}

\subsubsection{Key to the females}

1 (14) Radial vein shorter than basal vein.

2 (5) Radial vein slightly curved and in apical half swollen with anterior side concave and backside convex. Stigma as pale as basal vein, with a long dorsal seta. Costal cell without setae or with one seta.

3 (4) Propodeal disc narrowing behind, anteriorly without median incision; sculpture between submedian carinae reticulate. Notauli short. pedatus (Say)

4 (3) Propodeal disc with parallel sides, anteriorly with median incision; sculpture between submedian carinae transversely wrinkled. Notauli linear, long. seticornis (Duchaussoy)

5 (2) Radial vein straight or almost straight, not swollen apically. Stigma brownish, slightly darker than basal vein, with short dorsal setae. Apex of costal cell often with several small setae.

6 (9) Stigma extending further apicad on anterior margin than near the origin of the radial vein. Costal cell with 6-12 setae. Scape infuscate at least on upper surface near base. Femora dark.

7 (8) Fore wing hyaline. Costal cell apically with 6-10 setae. femoralis (Förster)

8 (7) Fore wing apically with infuscation which is stronger near anterior margin. Costal cell apically with 7-12 setae. fumimarginalis Vikberg, sp. n.

9(6) Stigma not or hardly produced further on anterior margin than near the origin of the 
radial vein. Costal cell with $0-9$ setae. Scape pale. Femora pale or slightly infuscate.

10(11) Anterior angle of ocellar triangle $90^{\circ}$. Propodeal disc transverse, medially 0.74 as long as broad behind spiracles. foersteri Kieffer

11(10) Anterior angle of ocellar triangle acute. Propodeal disc less transverse, medially $0.87-0.96$ as long as broad behind spiracles.

12(13) Propodeal disc medially 0.87 as long as broad behind spiracles. Legs beyond coxae brownish yellow.

sp. (Japan, Honshu)

13(12) Propodeal disc medially 0.96 as long as broad behind spiracles. Femora slightly infuscate.

parcepilosus Vikberg sp. n.

14 (1) Radial vein as long as or longer than basal vein.

15(16) Radial vein $1.0-1.17$ as long as basal vein. Costal cell with 2-8 setae.

borealis Vikberg, sp. $\mathrm{n}$.

16(15) Radial vein 1.2-1.8 as long as basal vein. Costal cell with 15-22 setae. virilis Vikberg, sp. $\mathrm{n}$.

\subsubsection{Key to the males}

1 (2) Radial vein slightly curved, with apical half swollen, shorter (0.7-0.8) than basal vein. Stigma yellowish, as pale as basal vein, with one long dorsal seta. Dorsal side of costal cell with 11-14 setae, basal 0.3 of cell glabrous. Pedicel shorter $(0.8-$ $0.9)$ than flagellomere 1.

pedatus (Say)

2 (1) Radial vein apically not swollen. Stigma brownish, slightly darker than basal vein, dorsal setae short. Costal cell setose throughout, with 20-30 setae. Pedicel shorter, as long as or longer than flagellomere 1.

3 (4) Radial vein shorter (0.8-0.9) than basal vein. Stigma apically oblique, distinctly longer on anterior margin of wing than near the origin of the radial vein. fumimarginalis Vikberg sp. $\mathrm{n}$.

4 (3) Radial vein about as long as or longer than basal vein. Stigma apically more or less truncate.

5 (6) Femora and tibiae brownish yellow.

6 (5) Femora and tibiae dark.

7 (8) Radial vein about as long (1.0-1.1 times) as basal vein.

parcepilosus Vikberg sp. n.

8 (7) Radial vein longer (1.14-1.8 times) than basal vein.

9(10) Radial vein $1.14-1.17$ as long as basal vein. borealis Vikberg sp. $\mathrm{n}$.

10(9) Radial vein 1.5-1.8 as long as basal vein. virilis Vikberg sp. $\mathrm{n}$.

Note that males of $L$. pedatus and L. fumimarginalis are associated with females with a fair certainty. Of the other species, only 1-2 males could be examined, and the combination with the females is more or less tentative or the species is not identified.

\subsection{Alphabetical list of, and notes on, all previous (nominal) species reported from the Palaearctic area}

After the name of the species, the sex(es), the type locality, and some of the characters of the original description with possible comments are provided.

L. agraensis Kurian, 1955. , India: Agra. Femora reddish brown; notauli absent; radius ca. $3 / 4$ as long as basalis; apical $2 / 3$ of fore wing light brown.

L. anfractuosus Benoit, 1952. + , Algeria: Biskra. Femora dark chestnut ("brun-châtain"); mandibles with 4 teeth; radius a little longer than half of basalis; fore wing in apical half infumate.

L. anthrenivorus Trani, 1909. qô, Italy: Naples. Femora yellowish red; notauli absent; fore wing apically infumate.

L. antropovi Gorbatovskij, 1995. क, Russian Far East: Ussuriisk (neotype; Gorbatovskij 1998). Legs from black to brown; radius slightly longer than basalis (in fig. 82: 2); POL:OOL $1.25-1.35$.

L. berlandi (Benoit, 1963; Allepyris). + , Morocco: Agadir. Femora black; mandible with 3 teeth; fore wing infumate with transverse hyaline band near pterostigma. 
L. bipartitus Kieffer, 1906. O’, France: Montde-Marsan. Femora brownish yellow; notauli complete; antenna brownish yellow.

L. elisae Russo, 1938. +ô, Italy: Pisciotta, Salerno. Female: femora ferruginous; radius shorter than basalis; female figured in Russo (1938) accurately with several details.

L. femoralis (Förster, 1860; Bethylus). §,, Germany: near Aachen. Neotype + , Netherlands: near Hilversum. See 3.1 .

L. foersteri Kieffer, 1914. New name for Bethylus rufipes Förster, 1860, nec Say, 1836. $+\hat{0}$, Germany: near Aachen. Lectotype 9 ; see 3.2 .

L. fulvipes Kieffer, 1906. + , Italy: Adda; and Spain: Pozuelo de Calatrava. Femora yellowish red; notauli absent; radialis shorter than basalis.

L. mesitioides (Duchaussoy, 1916; Allepyris). $\widehat{\lambda}$, Canary Islands: Teneriffe. Probably the male of L. seticornis; see 3.4 .

L. microneurus (Kieffer, 1906; Allepyris). , France: Dieppe. Perkins (1976) reported Laelius microneurus (Kieffer) from England and figured its fore wing. Allepyris microneurus may well be the same species as Laelius femoralis (Jeroen de Rond, pers. comm.).

L. nigricrus (Kieffer, 1906: Allepyris). ㅇ, France: Gray. Berland (1928) studied the holotype females of $A$. microneurus and $A$. nigricrus and could not find any difference between them. He synonymized the two species and figured the female of $A$. microneurus. A possible synonym of L. femoralis; see L. microneurus.

L. pedatus (Say, 1836; Bethylus). (), U.S.A.: Indiana. Seven synonym names from U.S.A. are given in Evans (1978). Found in the Netherlands (Mayhew \& Heitmans 2000), Germany (de Rond 2001), and Finland. See 3.3.

L. perrisi Kieffer, 1906. ㅇ, France: Mont-deMarsan. Femora yellowish red; notauli absent.

L. ruficrus (Kieffer, 1906; Allepyris). + , N. Italy: Trentino (neotype; Guiglia 1962). Femora red; pterostigma pale yellow; radius ca. $2 / 3$ as long as basalis.

L. seticornis (Duchaussoy, 1916; Allepyris). +, Canary Islands: Teneriffe. Redescription based on one female from La Palma; see 3.4.

L. tibialis Kieffer, 1906. O, France: Mont-deMarsan. Femora dark, blackish brown; notauli absent.
L. utilis Cockerell, 1920. + , U.S.A.: Lynchburg, Virginia. Femora dark, fore tibia bright ferruginous; fore wing apically clouded. Recorded from Sweden (Hedqvist 1975). See 3.3.

L. voracis Muesebeck, 1939. + , U.S.A.: Washington, D.C. Legs brownish to piceous; radius about as long as basalis, slightly curved; fore wing hyaline. Recorded from India: Uttar Pradesh (Ayyappa \& Chema 1952, Kurian 1954, 1955).

\section{Discussion}

Richards (1977) tabulated the characters of the apex of the male gaster of Bethylidae as follows: tergum 10 not separately developed, tergum 9 concealed and divided, and pygostyles absent. However, all males of Laelius which were studied in the present paper, have distinct pygostyles, each with two apical setae. Richards (1939) did not study any Laelius from Britain.

The genitalia of different species of Laelius are rather similar. Small differences are evident in the shape of the penis and aedeagal apodemes. The number of transverse setae on the ventral margin of cuspis varies from 2-3 (L. virilis, $L$. fumimarginalis), 3-4 (L. borealis, L. parcepilosus), 4-5 (L. pedatus), to 6-6 ( $L$. sp. from Bulgaria). The medial part of the cuspis has some strong hairs; their number varies from 2-2 (L. sp. from Bulgaria), 2-3 (L. pedatus), 3-3 (L. virilis), 3-4 (L. borealis), 4-4 (L. parcepilosus), to 4-5 (L. fumimarginalis).

Trjapitsyn (1978) keyed five European species on the basis of earlier literature; he used the form of claws as an important key character based on the wrong information given by Kieffer (1914), and Laelius femoralis was keyed under three different names. The claws of different species of Laelius have rather similar structure; the claws of males are similar but smaller.

Gorbatovskij $(1995,1998)$ described one new species, Laelius antropovi from the Russian Far East. The female POL:OOL index was given as $1.25-1.35$ which is very different from all species studied (the females have an index of $0.5-0.8$ ). The types of $L$. antropovi are not yet located in the Zoological Museum of the Moscow State University (Dr. Alexander Antropov, and Dr. Alexey 
Zinovjev, pers. comm.) and could not be examined.

This paper is just a beginning towards a revision of the Palaearctic species of Laelius. Many more types should be studied to identify the species correctly and to examine which names are valid after this comparison. We hope that now at least the females of the boreal species can be better evaluated than before.

Acknowledgements. The authors are grateful for the loan of specimens of Laelius, and other information, to the following curators or private collectors: Johan Abenius, Anders Albrecht, Alexander Antropov, Jeroen de Rond, KarlJohan Hedqvist, Juhani Itämies, Frank Koch, Christoph Kornmilch, Michael Madl, Pekka Malinen, Petri Martikainen, Stefan Schmidt, Stefan Schödl, Andreas Taeger, Mamoru Terayama, Einari Valleala, Kees van Achterberg, Gergely Várkonyi, Matti Viitasaari, Bert Viklund, and Alexey Zinovjev. Jeroen de Rond helped us by giving information on Central European species, and by carefully checking the manuscript and proposing many improvements.

\section{References}

Ashmead, W. H. 1893: A monograph of the North American Proctotrypidae. - Bulletin of the United States National Museum, Washington 45: 1-463, 18 plates.

Ayyappa, P. K. \& Cheema, P. S. 1952: An ectoparasite on the larvae of Anthrenus vorax Waterhouse. - Proceedings of the Indian Academy of Sciences series B 36: 215-222.

Benoit, P. L. G. 1952: Bethylidae (Hym.) nord africains nouveaux ou peu connus du Museo Civico di Storia Naturale di Genova. - Doriana. Annali du Museo Civico di Storia Naturale "G. Doria” Genoa 1(27): 17.

Benoit, P. L. G. 1963: Bethylides nord-africains recoltés par M. L. Berland. - Bulletin de Muséum National d'Histoire Naturelle serie 2, 35(1): 82-84.

Berland, L. 1928: Hyménoptères Vespiformes II. — Faune de France 19: 1-206.

Duchaussoy, A. 1916: Nouveaux Béthylides de l'Afrique du Nord et de l'Europe orientale (Hyménoptères). Bulletin de Société d'Histoire Naturelle de l'Afrique du Nord 7(5)(1914): 109-126.

Evans, H. E. 1964: A synopsis of the American Bethylidae (Hymenoptera, Aculeata). — Bulletin of the Museum of Comparative Zoology Harvard University 132(1): $1-222$.

Evans, H. E. 1978: The Bethylidae of America North of Mexico. - Memoirs of the American Entomological Institute 27: 1-332.

Förster, A. 1860: Eine Centurie neuer Hymenopteren. Decheniana [Verhandlingen des Naturhistorischen
Vereins der preussischen Rheinlande und Westphalens] 17: 93-153.

Gorbatovskij, V. V. 1995: 58. Fam. Bethylidae - betilidi. - In: Ler, P. A. (ed.), Key to the insects of Russian Far East vol. 4. Neuropteroidea, Mecoptera, Hymenoptera. Part 1: 179-190. Sankt Petersburg, Nauka, 606 pp. (In Russian)

Gorbatovskij, V. V. 1998: Supplement 58. Fam. Bethylidae - betilidi. - In: Ler, P. A. (ed.), Key to the insects of Russian Far East vol. 4. Neuropteroidea, Mecoptera, Hymenoptera. Part 3: 680-682. Vladivostok, Dal'nauka, 708 pp. (In Russian)

Gordh, G. \& Móczár, L. 1990: A catalog of the world Bethylidae (Hymenoptera: Aculeata). - Memoirs of the American Entomological Institute 46: 1-323.

Guiglia, D. 1962: Un nuovo genere della famiglia Bethylidae che attacca l'uomo. Ulteriori osservazioni sulla puntura dello Scleroderma domesticum Latreille (Hymenopt.: Bethylidae). - Annali do Museo Civico di Storia Naturale Giacomo Doria Genoa 73: 189-195.

Hedqvist, K.-J. 1975: Notes on Embolemidae and Bethylidae in Sweden with descriptions of a new genus and species (Hym., Bethyloidea). — Entomol. Tidskrift 96(3-4): 121-132.

Hellén, W. 1953: Übersicht über die Bethyliden und Dryiniden Finnlands. - Notulae Entomol. 33(3-4): 88-102.

Huber, J. T., \& Sharkey, M. J. 1993: Chapter 3 Structure.In: Goulet, H., \& Huber, J. T. (eds.), Hymenoptera of the world: an identification guide to the families: 1359. Research Branch Agriculture Canada, Ottawa, Ontario, vii +668 pp.

Iwata, K. 1941: (Natural enemy to Anthrenus verbaci [sic] Linnaeus.) - Kontyu 15: 50-51. [In Japanese]

Kieffer, J. J. 1905: Proctotrypides. In: André, E. (ed.), Species des Hyménopterès d'Europe \& d'Algérie 9: 65288. A. Hermann, Paris.

Kieffer, J. J. 1906: Proctotrypides. — In: André, E. (ed.), Species des Hyménopterès d'Europe \& d'Algérie 9: 289-551. A. Hermann, Paris.

Kieffer, J. J. 1914: Bethylinae. — Das Tierreich 41: 228 595.

Krombein, K. V. 1979: Superfamily Bethyloidea. — In: Krombein, K. V., Hurd, P. D., Smith, D. R. \& Burks, B. D. (eds.), Catalog of Hymenoptera in America North of Mexico 2: 1203-1251. Smithsonian Institution Press, Washington, D. C., xvi + pp. 1199-2209.

Kurian, C. 1954: Descriptions of five new and records and redescriptions of two known Bethyloidea (Parasitic Hymenoptera) from India. - Agra University Journal of Research. Science 3(2): 417-439.

Kurian, C. 1955: Bethyloidea (Hymenoptera) from India. - Agra University Journal of Research, Science 4(1): 67-155.

Martikainen, P. 2001: Conservation of threatened saproxylic beetles: significance of retained aspen Populus tremula on clearcut areas. - Ecological Bulletins 49: 205-208.

Mayhew, P. J., \& Heitmans, W. R. B. 2000: Life history correlates and reproductive biology of Laelius pedatus 
(Hymenoptera: Bethylidae) in the Netherlands. — European Journal of Entomology 97: 313-322.

Mertins, J. W. 1980: Life history and behavior of Laelius pedatus, a gregarious bethylid ectoparasitoid of Anthrenus verbasci. - Annals of the Entomological Society of America 73(6): 686-693.

Mertins, J. W. 1985: Laelius utilis (Hym. Bethylidae), a parasitoid of Anthrenus fuscus (Col.: Dermestidae) in Iowa. - Entomophaga 30(1): 65-68.

Muesebeck, C. F. W. 1939: The North American species of the genus Laelius Ashmead (Hymenoptera, Bethylidae). - Proceedings of the Biological Society of Washington 52: 171-176.

Muesebeck, C. F. W., \& Walkley, L. M. 1951: Superfamily Bethyloidea. - In: Muesebeck, C. F. W., Krombein, K. V., \& Townes, H. K. (eds), Hymenoptera of America North of Mexico - Synoptic catalog: 726-734. United States Department of Agriculture, Agriculture monograph 2, Washington, D. C., 1420 pp., 1 map.

Perkins, J. F. 1976: Hymenoptera Bethyloidea (excluding Chrysididae). - Handbooks for the identification of British insects 6, part 3(a): 1-38.

Richards, O. W. 1939: The British Bethylidae (s. 1.) (Hymenoptera). - Transactions of the Royal Entomological Society of London 89(8): 185-344.

Richards, O. W. 1977: Hymenoptera Introduction and key to families Second edition. - Handbooks for the identification of British insects 6(1): 1-100.

Rond, J. de 2001: Bethylidae. — Entomofauna Germanica 4: 117-119.

Russo, G. Y. 1938: Contributo alla conoscenza dei coleotteri scolitidi fleotribo: Phloeotribus scarabaeoides (Bern.) Fauv. Parte seconda biografia, simbionti, danni e lotta. - Bollettino del Laboratorio di Entomologia Agraria Portici 2: 1-420.
Say, T. 1836: Descriptions of new species of North American Hymenoptera and observations on some already described. - Boston Journal of Natural History 1(3): 210-305.

Snodgrass, R. E. 1941: The male genitalia of the Hymenoptera. - Smithsonian Miscellaneous Collections 99(14): 1-86, 33 plates.

Söderman, G., \& Vikberg, V. 2003: Suomen myrkkypistiäisten luettelo ja levinneisyys [Checklist and distribution of Finnish Aculeata (Hymenoptera, Apocrita, Aculeata)]. — Sahlbergia 7 (2002): 41-66. [In Finnish with English summary]

Trani, E. 1909: Di un nuovo proctotrupide parassita delle larve degli Anthrenus museorum. - Annuario del Museo zoologico della r. università di Napoli (Nuova serie) 3(4): 1-6, plate 1.

Trjapitsyn, V. A. 1978: Family Bethylidae (bethylids). In: Trjapitsyn, V. A. (ed.), Keys to the insects of the European part of the USSR 3 (2): 7-16. Keys to the fauna of the USSR 120: xii + 773 pp. (In Russian; English translation, Oxonian Press Pvt. Ltd., New Delhi, 1988, 1341 pp.)

Vance, A. M. \& Parker, H. L. 1932: Laelius anthrenivorus Trani, an interesting bethylid parasite of Anthrenus verbasci L. in France. - Proceedings of the Entomological Society of Washington 34(1): 1-7.

Vikberg, V., \& Koponen, M. 2001: Two dryinid species new for Fennoscandia with a re-evaluation of the generic division of N. European Gonatopodinae (Hymenoptera, Dryinidae). — Entomol. Fennica 12: 33-38.

Yamada, Y. 1955: Studies on the natural enemy of the woollen pest, Anthrenus verbaci [sic] Linné (Allepyris microneurus Kieffer) (Hymenoptera, Bethylidae). Mushi 28(3): 13-30, plates 4-5, tables 1-11. 